\title{
Genetics of primary hyperaldosteronism
}

\author{
Ravi Kumar Dutta', Peter Söderkvist ${ }^{1}$ and Oliver Gimm² \\ 1Department of Clinical and Experimental Medicine, Medical Faculty, Linköping University, Linköping, Sweden \\ 2Department of Surgery, County Council of Östergötland, Department of Clinical and \\ Experimental Medicine, Medical Faculty, Linköping University, Linköping, Sweden
}

Correspondence should be addressed to O Gimm

Email

oliver.gimm@liu.se

\begin{abstract}
Hypertension is a common medical condition and affects approximately $20 \%$ of the population in developed countries. Primary aldosteronism is the most common form of secondary hypertension and affects $8-13 \%$ of patients with hypertension. The two most common causes of primary aldosteronism are aldosterone-producing adenoma and bilateral adrenal hyperplasia. Familial hyperaldosteronism types I, II and III are the known genetic syndromes, in which both adrenal glands produce excessive amounts of aldosterone. However, only a minority of patients with primary aldosteronism have one of these syndromes. Several novel susceptibility genes have been found to be mutated in aldosterone-producing adenomas: KCNJ5, ATP1A1, ATP2B3, CTNNB1, CACNA1D, CACNA1H and ARMC5. This review describes the genes currently known to be responsible for primary aldosteronism, discusses the origin of aldosterone-producing adenomas and considers the future clinical implications based on these novel insights.
\end{abstract}

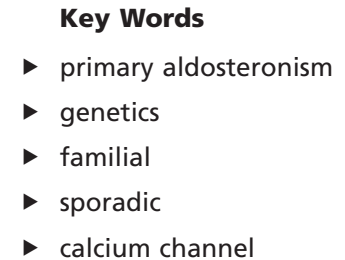

Endocrine-Related Cancer (2016) 23, R437-R454

\section{Introduction}

Hypertension, which is characterized by the presence of high blood pressure, is a serious medical condition. According to the World Health Organization (WHO), approximately $40 \%$ of adults aged 25 and older have hypertension. It is divided into two forms, primary or essential hypertension that accounts for 90-95\% of all hypertension cases and secondary hypertension. Concerning secondary hypertension, primary aldosteronism (PA) accounts for $8-13 \%$ of the patients with unselective hypertension (Funder 2012). The two most common causes of primary aldosteronism are an aldosterone-producing adenoma (APA) and bilateral adrenal hyperplasia (BAH); both are characterized by a constitutive overproduction of aldosterone.

APAs are also known as Conn adenomas (named after the American endocrinologist Jerome W Conn) and are characterized by the presence of tumors in the adrenal cortex (Conn 1966). Unilateral APA is most commonly found in patients; bilateral APAs are rarely reported. Patients with APAs are often identified due to hypertension that is difficult to control with medication. To screen patients, the guidelines recommend the measurement of the aldosterone-to-renin ratio (ARR), which may be accompanied by hypokalemia (Funder et al. 2008, Nishikawa et al. 2011). If the ARR is $>200$, confirmative tests such as the captopril challenge test, the upright furosemide-loading test or the saline-loading test should be performed. Unilateral adrenalectomy often normalizes or markedly improves the blood pressure in patients with APAs (Funder et al. 2008, Nishikawa et al. 2011). The majority of APAs are only $1-3 \mathrm{~cm}$ in size (Choi et al. 2011, Mulatero et al. 2012, Taguchi et al. 2012,

Published by Bioscientifica Ltd. 
Azizan et al. 2012a, Azizan et al. 2013, Beuschlein et al. 2013, Dutta et al. 2014, Zilbermint et al. 2015, Scholl et al. $2015 b$ ). APAs may occur in patients of all ages, but a high prevalence is seen in patients $40-50$ years of age.

Bilateral adrenal hyperplasia (BAH) is another form of PA, which accounts for $60-70 \%$ of patients with PA (Zennaro et al. 2015). It is diagnosed if adrenal venous sampling shows hyperaldosterone secretion from both adrenals. Standard treatment involves antagonists of the mineralocorticoid receptor, e.g., spironolactone. BAH is also associated with genetic syndromes such as familial hyperaldosteronism types I, II or III, in which both adrenal glands produce excessive amounts of aldosterone.

Aldosterone is a mineralocorticoid that under physiological conditions is produced by the zona glomerulosa of the adrenal cortex and regulated by the renin-angiotensin system (Morgan et al. 1996, Tanabe et al. 1998). The proteolytic enzyme, renin, converts angiotensinogen to angiotensin I, which is subsequently cleaved by angiotensinogen-converting enzyme (ACE) to angiotensin II (Fig. 1). Next, angiotensin II binds to angiotensin receptors on the surface of adrenal cortex cells, which leads to the production of aldosterone. Moreover, aldosterone binds to the mineralocorticoid receptor (MR) in different segments of the renal tubule. It activates the expression of the epithelial $\mathrm{Na}^{+}$channel (ENaC), $\mathrm{Na}^{+}-\mathrm{K}^{+}$-ATPase and $\mathrm{NaCl}$ cotransporter, which leads to the reabsorption of sodium and chloride ions (Garty \& Palmer 1997, Rossier et al. 2013, Czogalla et al. 2016). In addition, aldosterone production and secretion by the adrenals and the antidiuretic hormone (ADH) from the pituitary gland further contribute to the increase in blood pressure by regulating the reabsorption of water in the collecting ducts of the kidney (Share \& Crofton 1982). Aldosterone thus plays a central role in the regulation of blood pressure mainly by acting on the distal tubules and collecting ducts of the nephron. To a lesser extent, the adrenocorticotropic hormone (ACTH) also stimulates the secretion of aldosterone from adrenals (Gallo-Payet 2016). In healthy adults, the adrenal cortex produces $20-200 \mu \mathrm{g}$ of aldosterone per day.

The two most important physiological stimuli of aldosterone production are angiotensin II and the quantity of serum potassium (Fig. 1) (Tanabe et al. 1998). Decreased blood volume activates the renin-angiotensin system, in which angiotensin II signals via the angiotensin receptor (Fig. 1). The difference in $\mathrm{K}^{+}$concentration across the membrane sets the resting membrane potential; both hyperkalemia and hypokalemia cause depolarization of the membrane and generate an action potential to open a voltage-gated $\mathrm{Ca}^{2+}$ channel (Spat 2004). An enhanced intracellular $\mathrm{Ca}^{2+}$ concentration provides the normal signal for aldosterone production. In PA, autonomous production of aldosterone is found independent of angiotensin II (Funder 2012).

Research of PA and familial cases of hyperaldosteronism has accelerated the mechanistic insights of how different genes are linked to these diseases. Nextgeneration sequencing of APA samples has uncovered mutations in several novel genes: KCNJ5, ATP1A1,

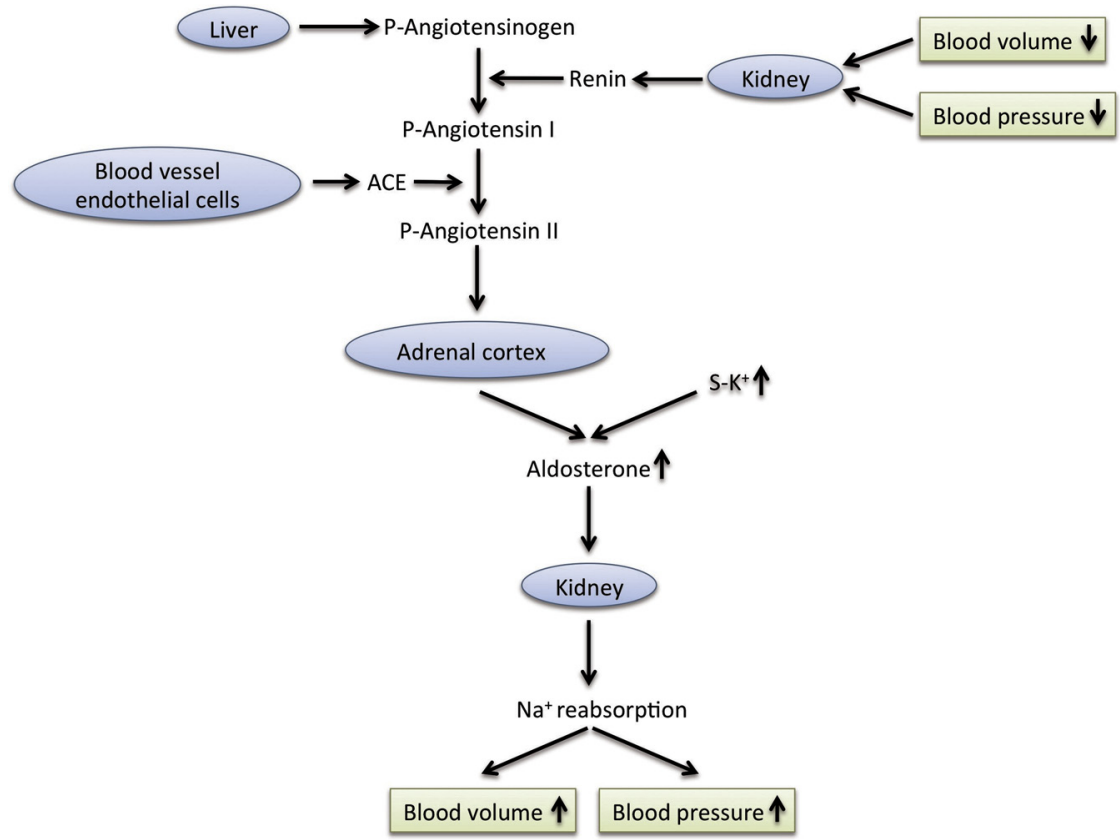

Figure 1

The renin-angiotensin system and aldosterone production under normal physiologic conditions. The liver continously produces angiotensinogen that is released into the plasma. When the blood pressure and volume decreases, the kidney granular cells start to produce renin, which cleaves angiotensinogen into angiotensin I. Angiotensin I is subsequently cleaved into angiotensin II, which binds to angiotensin II binding receptors $\left(\mathrm{AT}_{1 \mathrm{~A}}, \mathrm{AT}_{1 \mathrm{~B}}\right.$ and $\mathrm{AT} \mathrm{T}_{2}$ ) on zona glomerulosa cells of the adrenal cortex. This triggers the production of aldosterone. Aldosterone binds to the mineralocorticoid receptor in the kidney. ACE, angiotensinogen.
(C) 2016 Society for Endocrinology Printed in Great Britain
Published by Bioscientifica Ltd. 
ATP2B3, CTNNB1, CACNA1D, CACNA1H and ARMC5 (Choi et al. 2011, Mulatero et al. 2012, Azizan et al. 2012a, 2013, Taguchi et al. 2012, Beuschlein et al. 2013, Dutta et al. 2014, Zilbermint et al. 2015, Scholl et al. 2015b). So far, these identified genes are mutated in approximately $60 \%$ of patients with APAs. Still, the genetic factors that contribute to APA in the remaining $40 \%$ of patients are unknown. Here, we review the current knowledge regarding the genetics that contribute to PA.

\section{Genes associated with hereditary hyperaldosteronism}

\section{Familial hyperaldosteronism type I}

Sutherland and coworkers described the first familial hyperaldosteronism type I (FH-I) or glucocorticoidremedial aldosteronism (GRA) in their case report of a father and son suffering from hypertension due to hyperaldosteronism in 1966 (Sutherland et al. 1966). FH-I has been found in $0.5-1 \%$ of the adult population with PA as opposed to children with PA, where FH-I is found in 1-3\% of cases (Aglony et al. 2011, Carvajal et al. 2012). Among patients or within a family, FH-I is characterized by the presence of bilateral adrenal hyperplasia or a rare adrenal nodule exhibiting variable clinical and biochemical features (Fallo et al. 2004, Aglony et al. 2011). Patients with FH-I come to clinical attention early in life (Table 1). However, some patients exhibit a mild clinical phenotype, and even normotensive patients have been reported (Fallo et al. 2004). A high rate of cerebrovascular complications has been found in patients with GRA (Litchfield et al. 1998). There is no gender bias found among patients. Sutherland and coworkers found that treatment with dexamethasone, a suppressor of the ACTH, suppressed hypertension and decreased the aldosterone level (Sutherland et al. 1966).

The molecular etiology of FH-I was first elucidated by Lifton and coworkers in 1992. This study reported that patients with FH-I inherit a chimeric CYP11B1 and CYP11B2 hybrid gene. This hybrid gene includes the promoter region of $C Y P 11 B 1$ and the majority of the coding sequence of CYP11B2 (Lifton et al. 1992a). Consequently, aldosterone production in these patients is regulated by ACTH instead of angiotensin II. As a result, the aldosterone production follows a circadian secretion pattern with cortisol. Of note, the hybrid gene was found to be expressed in all cell layers of the adrenal cortex. In subsequent studies, Lifton and coworkers and Pascoe and coworkers showed that the crossing-over breakpoints of $C Y P 11 B 1 / B 2$ differ among cases, which suggest that the mutations arose independently in each individual (Pascoe et al. 1992, Lifton et al. 1992b). Patients with FH-I display increased levels of the secreted hybrid steroids, 18-hydroxycortisol and 18-oxocortisol. Ion channels and transporters are not reported to be involved in this type of familial hyperaldosteronism.

\section{Familial hyperaldosteronism type II}

In 1992, Stowasser and coworkers first described a second form of hereditary hyperaldosteronism, which is a nonglucocorticoid remedial form of PA (Stowasser et al. 1992). Patients are diagnosed with familial hyperaldosteronism type II (FH-II) when at least two first-degree members of the same family have confirmed primary aldosteronism (either APA or BAH) and when FH-I and familial hyperaldosteronism type III (FH-III) have been

Table 1 Clinical and biochemical data of patients with familial hyperaldosteronism (FH).

\begin{tabular}{|c|c|}
\hline & FH-I \\
\hline Gene mutation & Hybrid CYP11B1/CYP11B2 \\
\hline Mode of inheritance & Autosomal dominant \\
\hline $\begin{array}{l}\text { Gender predominance } \\
\text { (male:female) }\end{array}$ & $1: 1$ \\
\hline Age at diagnosis & Variable, mostly young \\
\hline Hypertension & Normotensive to severely hypertensive \\
\hline Aldosterone levels & Normal to markedly increased \\
\hline Potassium level & Normal to low \\
\hline Hybrid steroid & Higher \\
\hline Adrenal morphology & $\begin{array}{l}\text { Normal or occasional evidence of } \\
\text { hyperplasia }\end{array}$ \\
\hline Adrenal lateralization & Bilateral \\
\hline Treatment & Dexamethasone or MRA \\
\hline
\end{tabular}

FH-II
unknown
Autosomal dominant
$1: 1$
Variable or like-APA
Normotensive to severely hypertensive
Normal to markedly increased
Normal to low
Normal or mildly elevated
APA/BAH
Unilateral or bilateral
Unilateral adrenalectomy or MRA

\begin{tabular}{l} 
FH-III \\
\hline KCNJ5 \\
Autosomal dominant \\
1:1 \\
Mostly in childhood \\
Severely hypertensive \\
Extremely high \\
Hypokalemic \\
Extremely high \\
Normal or BAH \\
Bilateral \\
Bilateral adrenalectomy
\end{tabular}

APA, aldosterone-producing adenoma; $\mathrm{BAH}$, bilateral adrenal hyperplasia; MRA, mineralocorticoid receptor antagonist. 
excluded. In FH-II, the clinical and biochemical features as well as the severity of the disease vary among patients and family members (So et al. 2005). The phenotype of FH-II may be uni- or bilateral hyperplasia, which is very similar to sporadic PA (Table 1). Besides age, aldosterone levels, potassium levels and hybrid steroids (18-hydroxycortisol and 18-oxocortisol) levels are in the range of those observed in patients with sporadic APA (Funder et al. 2008, Mulatero et al. 2011). Depending on the severity and phenotype, FH-II is treated with either adrenalectomy or mineralocorticoid receptor antagonists. The prevalence of FH-II is higher (approximately 6\%) when compared with other familial forms of PA, and unlike FH-I, the age of FH-II patients varies from 14 to 78 years (Mulatero et al. 2011).

The molecular etiology of FH-II is still unknown; however, the mode of inheritance found among FH-II families is autosomal dominant (So et al. 2005, Sukor et al. 2008). Genome-wide linkage analysis in one family showed that chromosome $7 \mathrm{p} 22$ is associated with FH-II (Lafferty et al. 2000). In a subsequent study, Sukor and coworkers obtained similar results using samples from five different families. However, sequencing of candidate genes in this chromosomal region has failed to identify causative mutations. Recently, Multero and coworkers identified germline mutations in KCNJ5 in patients considered to have FH-II but who actually suffered from FH-III instead (Mulatero et al. 2012).

\section{Familial hyperaldosteronism type III}

In 2008, Geller and coworkers first described the third form of familial hyperaldosteronism in their case study of a father and two daughters (Geller et al. 2008). The affected persons had severe hypertension in childhood with distinctive clinical and biochemical features (Table 1). They also exhibited high levels of hybrid steroids (18-hydrocortisol and 18-oxocortisol) accompanied with hypokalemia. Dexamethasone suppression tests unexpectedly increased both serum aldosterone and blood pressure levels. The adrenal size was unexpectedly large, and histopathology demonstrated an atrophic zona glomerulosa and diffuse hyperplasia in the zona fasciculata. Bilateral adrenalectomies normalized the patients' blood pressure and aldosterone levels. FH-III is characterized by the early onset of hypertension and the presence of bilateral adrenal hyperplasia exhibiting resistant hypertension with hypokalemia (Geller et al. 2008). Very severe clinical phenotypes have been found among patients with FH-III (Geller et al. 2008, Monticone et al. 2015a). However, one case reported by Monticone and coworkers described patients with a mild phenotype (Monticone et al. 2013).

In 2011, Choi and coworkers identified the genetic etiology behind FH-III by whole exome sequencing (Choi et al. 2011). A germline KCNJ5 mutation was identified in one affected person at p.T158A and a somatic mutation in sporadic APAs (Choi et al. 2011). Expression of mutant KCNJ5 leads to higher membrane depolarization, which results in voltage-gated calcium channels opening. In 2012, Scholl and coworkers identified KCNJ5 germline mutations in four families with FH-III (Scholl et al. 2012). The mutations targeted the same codon, p.G151E and p.G151R, which is part of a highly conserved selective filter region of the potassium channel.

\section{Genes associated with aldosterone- producing adenomas (APAs)}

\section{KCNJ5}

KCNJ5 encodes the potassium ion channel Kir3.4, is located on chromosome 11q24.3 and consists of 3 exons. Further, this gene encodes a membrane protein of 419 amino acids. Kir3.4 forms the ion channel as homo- or heterotetramers with Kir3.1 (Corey \& Clapham 1998). This channel is expressed in different tissues including the heart, central and peripheral neurons, various endocrine tissues as well as nonexcitable structures such as blood platelets (Marionneau et al. 2005, Mintert et al. 2007, Choi et al. 2011, Monticone et al. 2012). Immunohistochemical studies of the human adrenal cortex have established that Kir3.4 is localized mainly in the zona glomerulosa and the outer part of zona fasciculata. Inwardly rectifying potassium channels are a type of $G$ protein-gated ion channels (Corey \& Clapham 1998). Inward rectifier potassium ion channels are activated (opened) via a signal transduction cascade starting with ligand-stimulated $G$ protein-coupled receptors (GPCRs). GPCRs, in turn, release activated G protein $\beta \gamma$-subunits $(G \beta \gamma)$ from inactive heterotrimeric $G$ protein complexes $(G \alpha \beta \gamma)$. Finally, the $G \beta \gamma$ dimeric protein interacts with $G$ protein-regulated inwardly rectifying $\mathrm{K}^{+}$(GIRK) channels to open them, so that they become permeable to $\mathrm{K}^{+}$ions, resulting in the hyperpolarization of the cell membrane. Potassium channels share a highly conserved stretch of eight amino acids, the $\mathrm{K}^{+}$channel signature sequence, that forms the selective filter region for $\mathrm{K}^{+}$ions (Heginbotham et al. 1994). The Kir3.4 channel is an inward rectifier channel that is very selective for monovalent ions and remarkably discriminate between

Published by Bioscientifica Ltd. 


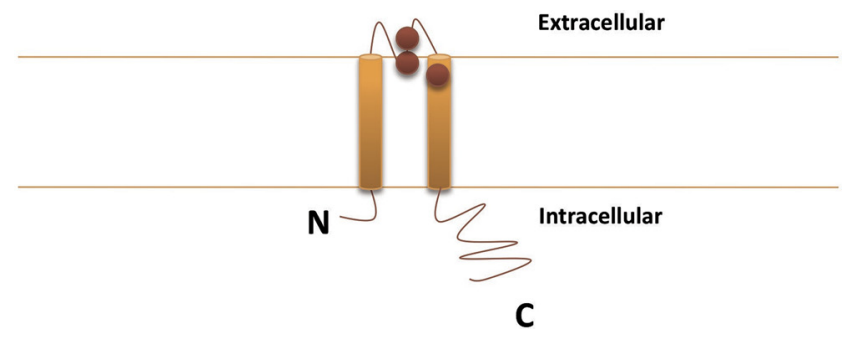

Figure 2

Showing one subunit of the Kir3.4 channel. Red circles indicate the most frequently found somatic and germline mutations in aldosteroneproducing adenomas.

$\mathrm{K}^{+}$and $\mathrm{Na}^{+}$ions (Roux 2005). Loss-of-function germline mutations in KCNJ5 have been reported in congenital long QT syndrome (Yang et al. 2010).

Choi and coworkers identified germline and somatic mutations in KCNJ5 by whole exome sequencing of samples from patients with either the familial or sporadic form of APA (Choi et al. 2011). Two hot spot somatic mutations were identified at p.G151R and p.L168R of the Kir3.4 channel (Fig. 2). The mutations p.G151R and p.L168R are situated on the highly conserved glycine-tyrosine-glycine (GYG) motif of the selective filter and the second transmembrane (TM) domain of $K C N J 5$, respectively. The mutations abolish the $\mathrm{K}^{+}$selectivity of the channel. Electrophysiological measurements of cells expressing both mutants show that the selectivity for the $\mathrm{K}^{+}$ion is lost, which leads to higher $\mathrm{Na}^{+}$conductance and depolarization of the cell. Further, this depolarization results in the opening of the voltagegated $\mathrm{Ca}^{2+}$ channels, which results in an influx of $\mathrm{Ca}^{2+}$ and increased aldosterone production.

Since the discovery of the KCNJ5 mutations in APAs by Choi and coworkers, there have been several confirmative reports from different research groups worldwide (Boulkroun et al. 2012, Taguchi et al. 2012, Dutta et al. 2014, Fernandes-Rosa et al. 2014, Murthy et al. 2014, Williams et al. 2014). Fernandes-Rosa and coworkers sequenced the hot spot region in 474 APAs collected from the European Network for the Study of Adrenal Tumor (ENSAT). KCNJ5 mutations were identified in 180 of the 474 samples (38\%), in which p.G151R (62.7\%) and p.L168R (36.1\%) were highly prevalent (Fernandes-Rosa et al. 2014). Recently, Murthy and coworkers identified one somatic mutation (p.E246K) and three polymorphisms (p.R52H, rs144062083; p.G247R, rs200170681; and p.E282Q, rs7102584) of KCNJ5 in sporadic cases (Murthy et al. 2014). All variants affected an amino acid that is highly conserved among species. When the polymorphism was expressed by
Xenopus oocytes, p.R52H and p.E282Q showed loss of the selectivity filter for the $\mathrm{K}^{+}$ion. The polymorphisms were inherited by the offspring ( $<30$ years), but no adenomas were found in their adrenals using a computed tomography scan.

Dekkers and coworkers sequenced multinodular adrenals for known genes associated with APAs (Dekkers et al. 2014) and, of interest, found one case having two different nodules with two different KCNJ5 mutations. In a similar study, Scholl and coworkers observed that APA with KCNJ5 mutations had larger clear cells with numerous lipid droplets and abundant microvascular cytoplasm (zona fasciculata-like cells) (Scholl et al. 2015a). Additionally, they identified that KCNJ5 mutations are more common in patients with uninodular rather than multinodular adrenal disease.

Several groups performed genome-wide expression array analysis to explore the expression pattern in sporadic APAs with and without KCNJ5 mutations (Boulkroun et al. 2012, Azizan et al. 2012b, Fernandes-Rosa et al. 2014, Monticone et al. 2015b). The mRNA expression of CYP17A1 (marker of zona fasciculata) was enhanced in KCNJ5-mutated tumors (Azizan et al. 2012b). Adenomas harboring KCNJ5 mutations showed a higher percentage of zona fasciculata-like cells, whereas wild-type KCNJ5 adenomas had a higher percentage of zona glomerulosa-like cells. However, Fernandes-Rosa and coworkers could not confirm any correlation between the KCNJ5 mutation status and the cellular morphology. They showed that $72 \%$ of APAs in their cohort were composed of $>50 \%$ of zona fasciculata-like cells. This divergent result is probably due to a different selection of the APA at this center. No obvious gene expression clustering pattern could be identified that differentiated APAs with and without KCNJ5 mutations (Boulkroun et al. 2012).

KCNJ5 mutations are present in approximately $30-65 \%$ of APA patients, with a higher prevalence in the Asian population and among females ( 70\%) (Table 2 ) (Taguchi et al. 2012, Williams et al. 2015). Among KCNJ5 mutations, G151R and L168R are found in approximately 90-99\% of cases, whereas other mutations are rare (Choi et al. 2011, Fernandes-Rosa et al. 2014). A summary of the reported KCNJ5 mutations is shown in Table 3.

\section{ATPases}

\section{ATP1A1}

ATP1A1 encodes for the $\alpha 1$ subunit of $\mathrm{Na}^{+} / \mathrm{K}^{+}$ATPase, which is a membrane-bound ion transporter of P-type ATPase.

Published by Bioscientifica Ltd 
Table 2 Clinical and biochemical data of patients with APAs.

\begin{tabular}{|c|c|c|c|c|c|}
\hline \multirow[b]{2}{*}{ Clinical parameter } & \multicolumn{5}{|c|}{ Gene mutated (frequency) } \\
\hline & $\begin{array}{c}\text { KCNJ5 } \\
35-50 \%\end{array}$ & $\begin{array}{c}\text { ATP1A1 } \\
5.2-8.2 \%\end{array}$ & $\begin{array}{c}\text { ATP2B3 } \\
0.9-1.7 \%\end{array}$ & $\begin{array}{l}\text { CACNA1D } \\
11 \%\end{array}$ & $\begin{array}{l}\text { CTNNB1 } \\
\text { (unknown) }\end{array}$ \\
\hline Gender predominance (frequency) & $\overline{\text { Females }(60-74 \%)}$ & $\overline{\text { Males }(75-89 \%)}$ & $\overline{\text { Females }(60-70 \%)}$ & $\overline{\text { Males }(67 \%)}$ & $\overline{\text { Majority female }}$ \\
\hline Age at diagnosis (years) & $35-50$ & $34-71$ & $33-60$ & $35-48$ & $24-65$ \\
\hline Preoperative plasma aldosterone (pmol/L) & $411-1200$ & $373-6963$ & $300-9567$ & 520-1012 & $672-2590$ \\
\hline $\begin{array}{l}\text { Preoperative plasma renin concentration } \\
\text { (ng/L) }\end{array}$ & $1-4.2$ & $1.3-5.2$ & $1.0-8.7$ & $1.2-4.7$ & $<2.0$ \\
\hline Adenoma size $(\mathrm{mm})$ & $12-25$ & $10-25$ & $12-25$ & $8-12$ & $9-30$ \\
\hline Preoperative SBP $(\mathrm{mmHg})$ & $140-170$ & $138-180$ & $150-167$ & $138-164$ & $130-150$ \\
\hline Preoperative DBP $(\mathrm{mmHg})$ & $93-110$ & $84-110$ & $90-111$ & $85-95$ & $85-95$ \\
\hline $\mathrm{K}^{+}$concentration $(\mathrm{mmol} / \mathrm{L})$ & $2.1-3.6$ & $2.5-3.5$ & $1.7-3.3$ & $2.8-3.3$ & $2.9-4.1$ \\
\hline
\end{tabular}

APA, aldosterone-producing adenoma; DBP, diastolic blood pressure; SBP, systolic blood pressure.

It is located on chromosome $1 \mathrm{p} 13.1$. It has 23 exons and 11 splice variants. In general, $\mathrm{Na}^{+} / \mathrm{K}^{+}$ATPases consist of $\alpha$ - and $\beta$-subunits. The $\alpha 1$ subunit is the most abundant and the major form found in the kidney and epithelial cells. $\mathrm{Na}^{+} / \mathrm{K}^{+}$ ATPases are expressed throughout the adrenal cortex; the highest mRNA expression is in the zona glomerulosa. The $\mathrm{Na}^{+} / \mathrm{K}^{+}$and ATP binding sites are located in the $\alpha$-subunit, whereas the $\beta$-subunits are responsible for

Table 3 Somatic and germline KCNJ5 mutations in patients with APAs.

\begin{tabular}{|c|c|c|}
\hline Coding alteration & Altered amino acid & Mutation type \\
\hline c. $155 \mathrm{G}>\mathrm{A}$ & p.R52H & $\begin{array}{l}\text { Germline (rare } \\
\text { polymorphism) }\end{array}$ \\
\hline c. $376 \mathrm{~T}>\mathrm{C}$ & p.W126R & Somatic \\
\hline $\begin{array}{l}\text { c.414- } \\
\text { 425dupCGCTTTCCTGTT }\end{array}$ & p.A139_F142dup & Somatic \\
\hline c. $433 \mathrm{G}>\mathrm{C}$ & p.E145Q & $\begin{array}{l}\text { Somaticl } \\
\text { germline }\end{array}$ \\
\hline c.433_434CCATTG & p.I144_E144insAl & Somatic \\
\hline c. $451 \mathrm{G}>\mathrm{A} / \mathrm{C}$ & p.G151R & $\begin{array}{l}\text { Somatic/ } \\
\text { germline }\end{array}$ \\
\hline c.451insATG & p.I150_G151insM & Somatic \\
\hline c. $452 \mathrm{G}>\mathrm{A}$ & p.G151E & Germline \\
\hline c. $455 \mathrm{~A}>\mathrm{G}$ & p.Y152C & Germline \\
\hline c. $461 \mathrm{~T}>\mathrm{G}$ & p.F154C & Somatic \\
\hline c.469_471delATC & p.I157del & Somatic \\
\hline c. $470 \bar{T}>G$ & p.I157s & Germline \\
\hline c.470_471delinsAA & p.I157K & Somatic \\
\hline c. $472 \mathrm{~A}>\mathrm{G}$ & p.T158A & $\begin{array}{l}\text { Somaticl } \\
\text { germline }\end{array}$ \\
\hline c. $503 \mathrm{~T}>\mathrm{G}$ & p.L168R & Somatic \\
\hline c. $730 \mathrm{G}>\mathrm{A}$ & p.E246K & Somatic \\
\hline c. $739 \mathrm{G}>\mathrm{A}$ & p.G247R & $\begin{array}{l}\text { Germline (rare } \\
\text { polymorphism) }\end{array}$ \\
\hline $\mathrm{c} .844 \mathrm{C}>\mathrm{G}$ & p.E282Q & $\begin{array}{l}\text { Germline } \\
\text { (polymorphism, } \\
2 \% \text { ) }\end{array}$ \\
\hline
\end{tabular}

Accession number: NM_000890.3; APA, aldosterone-producing adenoma. directing the $\alpha$-subunit to the plasma membrane (Einholm et al. 2007). $\mathrm{Na}^{+} / \mathrm{K}^{+}$ATPases transport three $\mathrm{Na}^{+}$ions in exchange for two $\mathrm{K}^{+}$ions, and this process is driven by the hydrolysis of ATP. The exchange of ions generates an electrochemical gradient across the membrane that facilitates the cellular uptake of ions. There are at least four isoforms of the $\alpha$-subunit identified. The $\alpha 1$ subunit is a $110 \mathrm{kDa}$ protein with more than 1000 amino acid residues. It has 10 transmembrane (TM) domains and a large cytoplasmic domain; $\mathrm{K}^{+}$ion binding sites are present between the helices of TM4, TM5 and TM6 (Morth et al. 2007). L104 and V332 interact with E334 and cooperate in $\mathrm{K}^{+}$binding and gating of the $\mathrm{K}^{+}$sites (Einholm et al. 2007).

By exome sequencing, Beuschlein and coworkers identified two somatic substitutions at p.L104R and p.V332G and one deletion at p.F100_L104 in ATP1A1 in $6.8 \%$ of the patients with APAs (16/328) (Fig. 3) (Beuschlein et al. 2013). The reported mutations are at highly conserved amino acid residues present in all ATPases. Mutations at L104 and V332 may abolish E334's ability to regulate $\mathrm{K}^{+}$ion influx. The mutant protein displayed severely impaired ATPase activity, which indicates decreased $\mathrm{Na}^{+}$and $\mathrm{K}^{+}$binding. The mutant also showed considerably higher levels of membrane depolarization when expressed by an adrenal cell line, H295R. Membrane depolarization leads to opening of a voltage-gated ion channel, increased intracellular calcium, and subsequently enhanced production of aldosterone (Beuschlein et al. 2013).

Azizan and coworkers sequenced DNA from 10 APAs, which consisted of zone glomerulosa-like cells (Azizan et al. 2013). They identified mutations at p.L104R and p.F100_L104del, which supports the critical function 


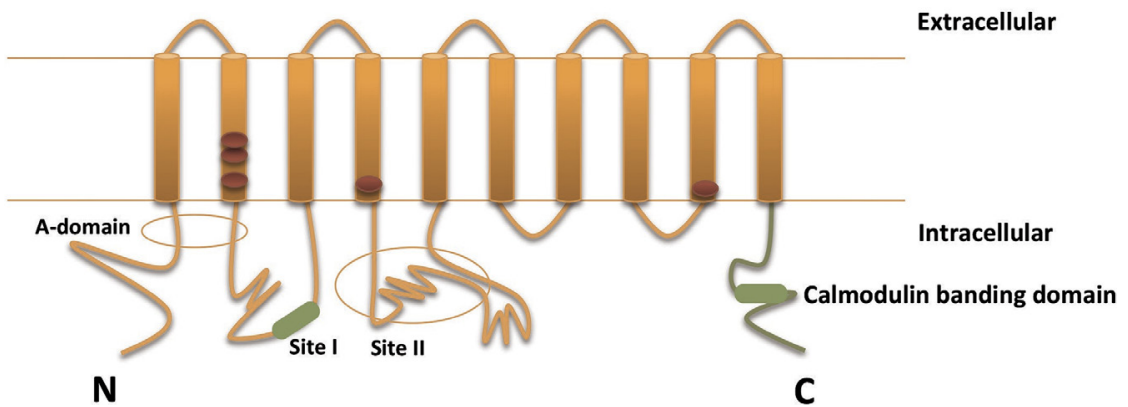

\section{Figure 3}

Illustrating the structure of $\mathrm{Na}^{+} / \mathrm{K}^{+}$ATPase subunit $\alpha 1$. Red circles indicate the mutations found in ATP1A1 in sporadic aldosteroneproducing adenomas. All mutations are located in the second and fourth transmembrane domain of ATP1A1. of L104. In addition, they found an in-frame deletion of residues 960-963 and a substitution of 963 by a serine (p.EETA963S). This mutation includes E961 (TM9) that has been identified in forming a third $\mathrm{Na}^{+}-$ specific binding site (Morth et al. 2007). When mutant p.EETA963S was expressed in Xenopus oocytes, the mutant ATPase still transports $\mathrm{K}^{+}$ions. However, mutant cells showed an enhanced inward current under normal physiological conditions. Williams and coworkers found a novel mutation at p.G99R that was associated with a severe phenotype with hypokalemia (Williams et al. 2014). G99 is in the transmembrane domain (TM1) and interacts with $\mathrm{I} 292$ and E334 in $\mathrm{K}^{+}$binding site I. Substitution of glycine for the large positive charge of arginine resulted in significantly increased expression of CYP11B2 and its transcription factor, NR4A2/Nur77 (Williams et al. 2014).

In a recent study, Stindl and coworkers expressed the mutants G99R, L104R and V332G in NCl H295R and looked at the effect on aldosterone production (Stindl et al. 2015). Among all the mutants, L104R showed the highest depolarization of the cell membrane in NCl H295R cells. However, expression of any of the mutants leads to an increase in intracellular $\mathrm{Na}^{+}$and to a decrease in $\mathrm{K}^{+}$ ions. Interestingly, L104R and V332G mutants resulted in leakage of $\mathrm{H}^{+}$and acidification of adrenal cells. Of note, an increase in extracellular $\mathrm{K}^{+}$resulted in an increase in $\mathrm{pH}$ in the mutant-expressing cells. In a subsequent study, acidification of control cells with acetate was found to increase CYP11B2 mRNA and aldosterone levels.

The clinical and biochemical data of patients with ATP1A1 mutations is shown in Table 2 and the ATP1A1 mutations are summarized in Table 4 . Most patients have the following mutations: p.L104R, p.V332G, deletion at p.F100_L104 and p. F959_E961. Mutations are present in $5-8 \%$ of patients with APAs and are more prevalent in males than in females.

\section{ATP2B3}

ATP2B3 encodes the plasma membrane calcium transporter, ATPase 3 (PMCA3), which belongs to the superfamily of P-type transporters. It is highly expressed in the adrenal cortex. ATP2B3 is a large gene of 20 exons located on chromosome Xq28. The $\mathrm{Ca}^{2+} \mathrm{ATPases}$ are conserved and have a single polypeptide chain organized into 10 transmembrane (TM) domains and 4 cytoplasmic loops. The cytoplasmic domains contain an actuator domain $\mathrm{A}$, a phosphorylation domain $\mathrm{P}$ and a nucleotide binding domain $\mathrm{N}$. The loop between TM4 and TM5 contains the phosphorylation and ATP binding sites. There are two calcium ion binding sites

Table 4 Somatic mutations in genes coding for ATPases in patients with APAs.

\begin{tabular}{|c|c|c|}
\hline Gene & Coding alteration & Altered amino acid \\
\hline \multirow[t]{6}{*}{ ATP1A1a } & c. $295 G>A$ & p.G99R \\
\hline & c.299_313del TCTCAATGTTACTGT & p.F100L \\
\hline & c. $311 \mathrm{~T}>\mathrm{G}$ & p.L104R \\
\hline & c.995T >G & p.V332G \\
\hline & c. $2879 A A G A G A C A G d e l$ & p.960-963del \\
\hline & $\& c .2887 \mathrm{G}>\mathrm{T}$ & p.A963S \\
\hline \multirow[t]{3}{*}{$A T P 2 B 3^{b}$} & $\begin{array}{l}\text { c.1270_1275delGTGCTG/or } \\
\text { c.1269_1274delTGTGCT }\end{array}$ & p.V424_L425 \\
\hline & $\begin{array}{l}\text { c.1272_1277delGCTGGT or } \\
\text { c.1273_1278delCTGGTC }\end{array}$ & p.L425_V426del \\
\hline & c.1277_1282delTCGTGG & p.V426_V427 \\
\hline
\end{tabular}

\begin{tabular}{ll}
\hline Mutation type \\
\hline Somatic \\
Somatic \\
Somatic \\
Somatic \\
Somatic \\
Somatic \\
Somatic \\
Somatic
\end{tabular}

Accession numbers: aNM_001160233.1; bNM_001001344.2; APA, aldosterone-producing adenoma. 


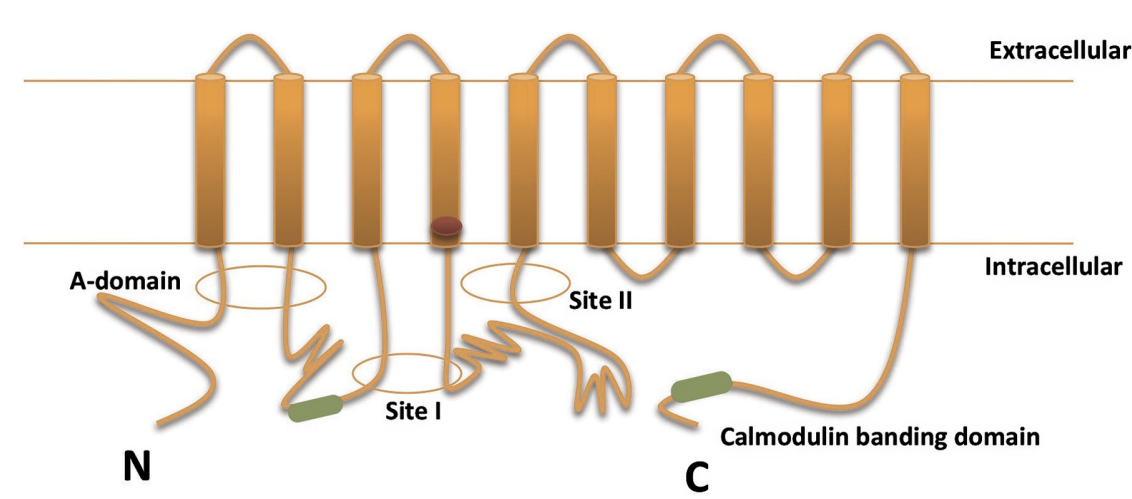

\section{Figure 4}

Illustrating the structure of the $\mathrm{Ca}^{2+}$ ATPase 3 subunit. Red circles indicate the mutations found in ATP2B3 in sporadic aldosterone-producing adenomas. All mutations are located in the fourth transmembrane domain of ATP2B3. This is the $\mathrm{Ca}^{2+}$ binding site.
(I and II). Site I is located in the space between TM4 and TM5; TM8 also contributes to this binding. Site II is formed on TM4. $\mathrm{Ca}^{2+}$ ATPases adopt an autoinhibitory state under normal physiological cytoplasmic $\mathrm{Ca}^{2+}$ concentrations, but ion transportation may be activated by binding of calmodulin to the calmodulin binding site. $\mathrm{Ca}^{2+}$ ATPases are characterized by the formation of a high-energy phosphorylated intermediate during the exchange of one $\mathrm{Ca}^{2+}$ ion for one $\mathrm{H}^{+}$ion. This exchange is at the expense of one ATP. Germline mutations in ATP2B3 have previously been reported in X-linked congenital cerebellar ataxia and Laminin syndromes (Baig et al. 2011, Cali et al. 2015).

Deletion mutations of ATP2B3 were reported together with ATP1A1 (Beuschlein et al. 2013) at p.L425_ V426del and p.V426_V427del, which are located in TM4 (Fig. 4). The amino acids L425, V426 and V427 interact with glutamic acid at 462 and are crucial for calcium binding. The mutations potentially lead to the distortion of both $\mathrm{Ca}^{2+}$ binding regions. Functional ex vivo studies have shown substantial depolarization in the mutated samples, indicating a selective advantage for these tumor cells.

To date, all mutations identified are in-frame deletions and located between the amino acids L424 and V429 (Table 4). ATP2B3 mutations have a low frequency (about $1-1.5 \%$ ) in APAs, are more prevalent in females, and are associated with a more severe form of APA (Table 2).

\section{Calcium channels}

\section{CACNA1D}

CACNA1D encodes the $\alpha 1$ subunit of L-type voltage calcium channel, $\mathrm{Ca}_{\mathrm{v}} 1.3$, and is located on chromosome 3p14.3. CACNA1D is a large gene with 49 exons and belongs to the $\mathrm{Ca}_{\mathrm{v}} 1$ family of proteins, which are activated by high-voltage depolarization and slow inactivation (Lipscombe et al. 2004). These L-type channels are expressed by endocrine tumors and are sensitive to selective inhibition by dihydropyridine (Catterall 2011). $\mathrm{Ca}_{\mathrm{v}} 1$ channels are formed by five subunits, $\alpha 1, \alpha 2, \beta, \gamma$ and $\delta$. The $\alpha 1$ subunit is the principle transmembrane and pore-forming subunit of the $\mathrm{Ca}_{\mathrm{v}} 1.3$ channel (Catterall 2011). CACNA1D encodes a protein of more than 2100 amino acids that are arranged in four homologous repeats (I-IV); each repeat contains six transmembrane segments (S1-S6) and a membrane-associated loop between the transmembrane segments S5 and S6. The S4 segment of each homologous domain serves as the voltage sensor for activation. It moves outward and rotates under the influence of an electric field, which initiates a conformational change that opens the pore. The S5 and S6 segments and the membrane-associated pore loop between them form the pore lining of the channel. The narrow external end of the pore is lined by the pore loop, which contains a pair of glutamate (E) residues in each domain. These glutamate residues are required for $\mathrm{Ca}^{2+}$ selectivity that is unique to a $\mathrm{Ca}^{2+}$ channel (Heinemann et al. 1992).

Exome sequencing of APAs identified somatic and de novo germline mutations in the CACNA1D gene (Scholl et al. 2013). The identified somatic mutations were at p.G403R and p.I770M, which are located on the S5 and S6 segments of domain I and II, respectively (Fig. 5 and Table 5). The identified mutations are at conserved sites in orthologs that range from invertebrates to humans. Segments S5 and S6 are important for pore formation and gating of the channel. Electrophysiological experiments revealed that the mutant channels open early (lower potential) and have a sustained activation. Early activation at a lower depolarization leads to an increase in $\mathrm{Ca}^{2+}$ entry, which is associated with enhanced aldosterone production (Scholl et al. 2013).

Scholl and coworkers further sequenced the CACNA1D S6 segment of domain I and II in 100 patients

Published by Bioscientifica Ltd. 


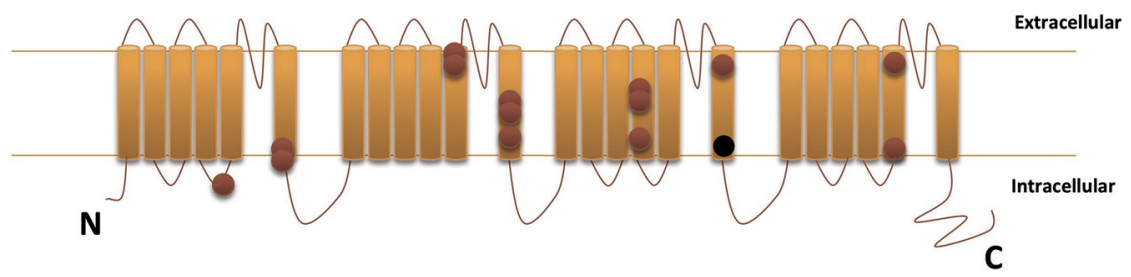

\section{Figure 5}

Showing the structure of the alpha subunit of $\mathrm{Ca}_{\mathrm{v}} 1.3$ channel. Red and black circles indicate the mutations found in CACNA1D and CACNA1H, respectively, in sporadic aldosterone-producing adenomas. CACNA1D mutations are distributed throughout the protein. that displayed an early onset of PA. The identified germline mutations were de novo at position p.G403R and p.I770M, and these patients had no family history of hypertension or seizure (Scholl et al. 2013). One case had a mutation at p.G403R and suffered from high blood pressure since birth. Further studies of this individual identified a significantly higher aldosterone-to-renin ratio and this patient also had hypokalemia. In addition, this patient had biventricular hypertrophy, a ventricular septal defect, pulmonary hypertension and second-degree heart blockage. Treatment with a calcium blocker normalized the hypertension as well as the biventricular hypertrophy. The second case carried a p.I770M mutation and was diagnosed with hypertension at age 5 . At birth, the patient was diagnosed with cerebral palsy, spastic quadriplegia, mild athetosis and seizures. Treatment with clonidine and spironolactone normalized the patient's blood pressure. So far, no other group has reported germline mutations in CACNA1D.

At the same time, Azizan and coworkers also reported somatic mutations in CACNA1D in zona glomerulosa-like

Table 5 Germline and somatic CACNA1D and CACNA1H mutations in patients with APAs.

\begin{tabular}{|c|c|c|c|}
\hline Gene & Coding alteration & $\begin{array}{l}\text { Altered } \\
\text { amino acid }\end{array}$ & Mutation type \\
\hline \multirow[t]{13}{*}{ CACNA1D } & c. $1201 \mathrm{G}>\mathrm{T}$ & p.V401|a & Somatic \\
\hline & c. $1207 G>C$ & p.G403R & $\begin{array}{l}\text { Somatic/de novo } \\
\text { germline }\end{array}$ \\
\hline & c. $1955 \mathrm{C}>\mathrm{T}$ & p.S652L & Somatic \\
\hline & c. $1964 \mathrm{~T}>\mathrm{C}$ & p.L655P & Somatic \\
\hline & c. $2222 \mathrm{~A}>\mathrm{G}$ & p.Y741C & Somatic \\
\hline & c. $2239 \mathrm{~T}>\mathrm{C}$ & p.F747L & $\begin{array}{l}\text { Somatic/de novo } \\
\text { germline }\end{array}$ \\
\hline & c. $2936 \mathrm{~T}>\mathrm{A}$ & p.V979N & Somatic \\
\hline & c.2992_2993GC>AT & p.A998I & Somatic \\
\hline & c. $2993 \mathrm{C}>\mathrm{T}$ & p.A998V & Somatic \\
\hline & c.3451G > T & p.V1151F & Somatic \\
\hline & c.3455T >A & p.I1152N & Somatic \\
\hline & c. $4012 \mathrm{G}>\mathrm{A}$ & p.V1338M & Somatic \\
\hline & c. $4057 G>A$ & p.V1353Ma & Somatic \\
\hline CACNA1Hb & c. $4645 A>G$ & p.M1549V & $\begin{array}{c}\text { Germline/ } \\
\text { de novo } \\
\text { germline }\end{array}$ \\
\hline
\end{tabular}

Accession numbers: NM_000720.3, aNM_001128840.2, bNM_021098; APA, aldosterone-producing adenoma.
APAs (Azizan et al. 2013). These mutations are scattered throughout the entire gene, although they always affect conserved amino acids or regions. Functional studies also showed that the channels were activated at lower membrane potentials. CACNA1D insertional germline mutations at p.Gly403_404 have previously been reported for sinoatrial node dysfunction and deafness syndrome (Baig et al. 2011, Pinggera et al. 2015). Recently, mutations in CACNA1D were also reported in patients with sporadic autism and intellectual disability at p.G403R (8A) and p.A749G (Baig et al. 2011, Pinggera et al. 2015). Notably, the reported mutation, p.G403, is also frequent in APAs. The mutation is located in the transmembrane S6 segment of repeat I and II, which highlights the importance of this region for proper channel function (Baig et al. 2011, Scholl et al. 2013).

During the last few years, the concept of APCCs (aldosterone-producing cell clusters) has given hope for finding the precursor cells of APAs. The development of specific antibodies against aldosterone synthase (AS; CYP11B2) and 11 -hydroxylase (CYP11B1) has allowed for the detection of cells that do and do not produce AS in APAs. Thus, CYP11B2- and CYP11B1-expressing cells can be determined. Studies with these antibodies reveal that the normal adrenal cortex consists of aldosteroneproducing cell clusters (APCCs) (Nishimoto et al. 2010). In subsequent studies, Nishimoto and coworkers sequenced the captured APCC for known genes and identified mutations in ATP1A1 and CACNA1D (Nishimoto et al. 2015). When they compared the mRNA expression of CYP11B2 in APCCs with different layers of the adrenal cortex, the mRNA expression in ZG (zona glomerulosa) cells was similar to that in APCCs. However, upon histological examination, the majority of samples showed a mixture of ZG- and ZF (zona fasciculata)-like cells.

More recently, Fernandes-Rosa and coworkers screened for mutations in functional secondary nodules of 27 patients with multinodular adrenal disease. They found two cases with somatic CACNA1D mutations in one nodule that also contained the somatic KCNJ5 mutation p.G151R in the secondary nodule (Fernandes-Rosa et al. 2015). In addition, a mutation in KCNJ5 was identified

Published by Bioscientifica Ltd 
in one of the secondary nodules at p.G151R without any other mutation in the known APA susceptibility genes.

CACNA1D mutations are predominantly found among males and are present in $3-11 \%$ of patients with APAs (Table 2). Unlike KCNJ5 mutants, CACNA1D mutants contain a mixture of zona glomerulosa and zona fasciculata cells in the adrenal adenomas (Akerstrom et al. 2015, Scholl et al. 2015a).

\section{CACNA1H}

CACNA1H encodes the $\alpha 1$ subunit of the T-type voltage calcium channel, $\mathrm{Ca}_{\mathrm{v}} 3.2$. The gene is situated on chromosome $16 \mathrm{p} 13.3$ and contains 35 exons that encode 2300 amino acids. $\mathrm{Ca}_{\mathrm{v}} 3.2$ channels are activated at higher negative membrane potentials and display voltage-dependent inactivation. The $\alpha 1$ subunit is the principle transmembrane portion and the poreforming subunit of $\mathrm{Ca}_{\mathrm{v}} 3.2$ channels. Expression of T-type channels in endocrine cells has been reported previously (Catterall 2011). The structure of CACNA1H is similar to CACNA1D, which is described in the CACNA1D section (Fig. 5).

Scholl and coworkers identified mutations in CACNA1H by exome sequencing of samples from 40 unrelated early-onset cases of hypertension (Scholl et al. 2015b). One hot spot mutation was identified at p.M1549V in the CACNA1H gene in five cases (Table 5). In three cases, the variant was inherited from a parent, whereas one case had a de novo germline mutation. In the last case, the mother had a de novo germline mutation, which was inherited by her daughter. The author further sequenced $C A C N A 1 H$ from an additional 1632 samples obtained from patients diagnosed with PA after the age of 10. They could not identify any mutation, which suggests that this mutation is specific for the early onset of hypertension (Table 2).

Methionine at 1549 is in a methionine-phenylalaninevaline (MFV) motif, which is conserved in orthologs from invertebrates to humans. In a previous study, substitution of methionine was found to delay the inactivation of the channel (Marksteiner et al. 2001). When the mutant was expressed in HEK293T cells, whole-cell patch clamp recording showed slow activation and a 10-fold delayed in inactivation. Slower inactivation leads to prolonged opening of the channel, which results in higher $\mathrm{Ca}^{2+}$ influx.

It is currently unknown whether germline mutations in CACNA1D and CACNA1H represent a new type of familial hyperaldosteronism. In particular, mutations in CACNA1H are specific for early onset of hypertension.

\section{Armadillo (ARM)-repeat-containing proteins}

\section{CTNNB1 ( $\beta$-catenin)}

Wnt signaling is a well-known signal transduction pathway that regulates aspects of embryonic development, solid cancers and stem cells (Anastas \& Moon 2013). Wnt signaling has been divided into two pathways: a $\beta$-catenin-dependent (canonical) and a $\beta$-catenin-independent (noncanonical) pathway. The best understood Wnt signaling transduction cascade is the Wnt/ $\beta$-catenin pathway. This is a receptor-mediated signaling pathway where the Frizzled/LRP6 receptor is the target of 19 highly conserved Wnt glycoprotein ligands (Morin et al. 1997, Angers \& Moon 2009). Until now, the Frizzled family of $G$ protein-coupled receptors (GPCRs), as well as the receptor tyrosine kinases (RTKs), ROR1 and ROR2, and the RTK-like protein RYK were identified as receptors involved in Wnt signaling (Angers \& Moon 2009). Upon binding of a Wnt ligand, the Frizzled/LRP6 receptor activates Disheveled cytoplasmic phosphoproteins, which inhibits phosphorylation of $\beta$-catenin (Fig. 6). $\beta$-Catenin then accumulates in the

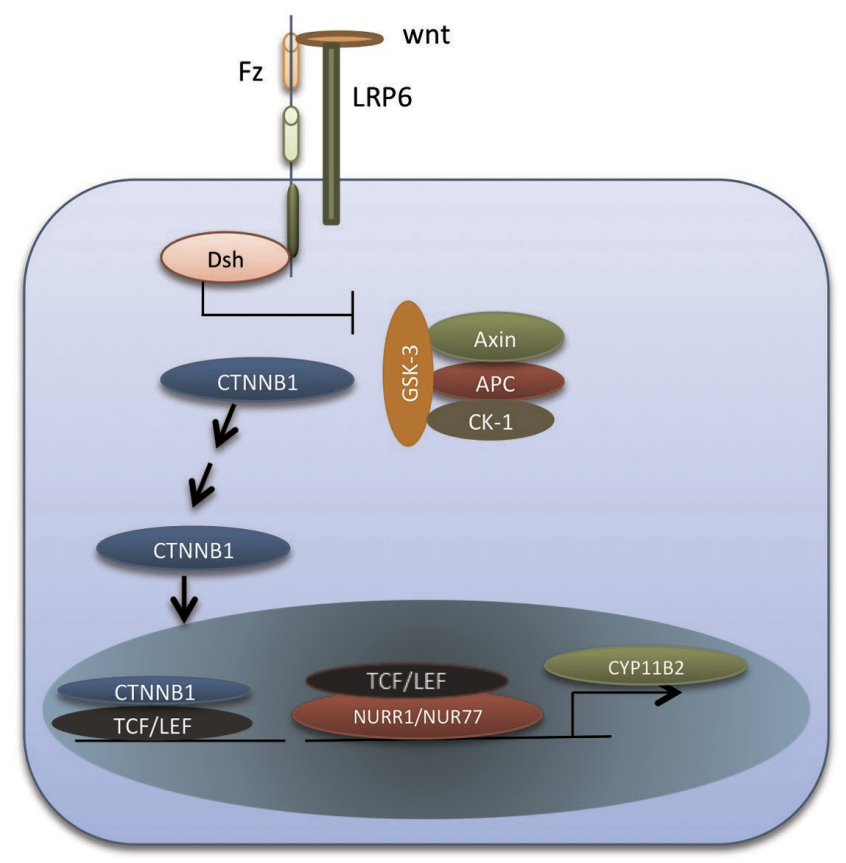

\section{Figure 6}

The Wnt/ $\beta$-catenin signaling pathway is involved in the formation of sporadic APA. Wnt ligands bind to frizzled (Fz) and its coreceptor, LRP5/6, to inhibit the degradation of $\beta$-catenin. The stabilized $\beta$-catenin translocates into the nucleus, which results in enhanced expression of the transcription factor TCF/LEF1 and ultimately leads to the expression of target genes. In aldosterone-producing adenomas, TCF/LEF1 binds to NURR1/NUR77, which is a trancription factor of CYP11B2.

Published by Bioscientifica Ltd. 


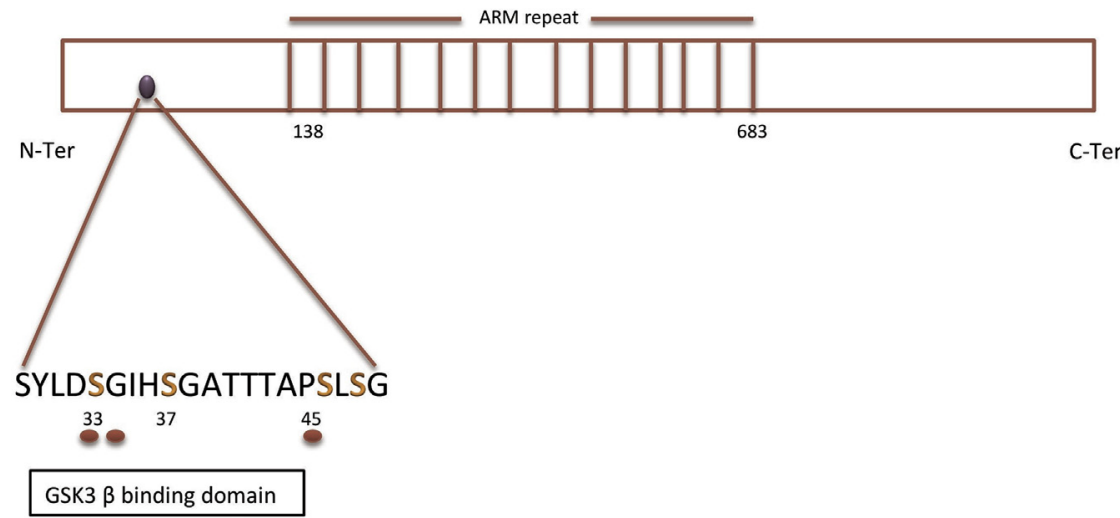

Figure 7

Structure of $\beta$-catenin. Glycogen synthase kinase 3 (GSK3) phosphorylate the serines (colored) in the GSK3 $\beta$ binding domain of $\beta$-catenin. The mutations are localized to the phosphorylation sites and indicated with red circles. nucleus, binds to lymphoid enhancer-binding factor (LEF) and $\mathrm{T}$ cell factor (TCF) proteins and acts as a transcriptional coactivator to modulate the expression of target genes. In the absence of Wnt ligands, $\beta$-catenin becomes phosphorylated by a degradation complex in the cytoplasm, which leads to its ubiquitin-dependent degradation (Fig. 6).

CTNNB1 consists of 15 exons, encodes for $\beta$-catenin, and is located on chromosome $3 \mathrm{p} 22.1$. Gain of function mutations in CTNNB1 have been identified in several different forms of cancer (e.g., colorectal cancer and ovarian cancer) (Kim et al. 2008). $\beta$-catenin signaling is essential for the development of the adrenal cortex, especially for adrenal glomerulosa. CTNNB1 is also frequently mutated in benign and malignant adrenocortical tumors that are not related to PA (Tissier et al. 2005).

CTNNB1 mutations (Fig. 7 and Table 6) have also been found in APAs (Azizan et al. 2013, Scholl et al. 2013, Shaikh et al. 2015), although the frequency of CTNNB1 mutations in APAs is very low (Table 2). Of note, the majority of CTNNB1 mutations are reported in female patients (Tissier et al. 2005, Azizan et al. 2013, Scholl et al. 2013, Teo et al. 2015, Scholl et al. 2015a). The mutations result in the loss of phosphorylation sites, which prevents ubiquitination by the E3 ligase, TrCP1 and further proteasomal degradation of $\beta$-catenin. Expression of $\beta$-catenin is found in the nuclear or cytoplasmic compartments in 70\% of APAs (Berthon et al. 2014). It appears to regulate the transcription of NURR1 and NUR77 (via its binding partners, LEF/TCF), which, in turn, is involved in the regulation of the aldosterone synthesis rate-limiting enzyme, CYP11B2 (Bassett et al. 2004, Berthon et al. 2014).

Berthon and coworkers observed that the Wnt/ $\beta$ catenin pathway is active in the adrenal cortex of transgenic mice, in which exon 3 of CTNNB1 was deleted (Berthon et al. 2010). Hyperproliferation in the zona glomerulosa was observed in 10-month-old mice, which resulted in primary hyperaldosteronism. $\beta$-Catenin activation resulted in the malignant characteristics of

Table 6 Mutations in genes coding for armadillo (ARM)-repeat-containing proteins in patients with APAs.

\begin{tabular}{|c|c|}
\hline Gene & Coding alteration \\
\hline \multirow{6}{*}{ CTNNB1a } & c. $98 \mathrm{C}>\mathrm{G}$ \\
\hline & c. $100 C>A$ \\
\hline & c. $134 \mathrm{C}>\mathrm{T}$ \\
\hline & C1276_1298insGACA_DelTCGTGGCTGTCCCAGAGGGCCT \\
\hline & c. $1641 \mathrm{G}>\mathrm{A}$ \\
\hline & c. $133 \mathrm{~T}>\mathrm{C}$ \\
\hline \multirow[t]{10}{*}{$A R M C 5^{b}$} & c. $41 \mathrm{~T}>\mathrm{A}$ \\
\hline & c. $466 \mathrm{C}>\mathrm{T}$ \\
\hline & c. $438 \mathrm{G}>\mathrm{A}$ \\
\hline & c. $508 \mathrm{~A}>\mathrm{G}$ \\
\hline & c. $968 \mathrm{G}>\mathrm{C}$ \\
\hline & c. $1505 \mathrm{G}>\mathrm{A}$ \\
\hline & c. $1520 \mathrm{C}>\mathrm{T}$ \\
\hline & C. $1928 C>T$ \\
\hline & c. $2476 C>A$ \\
\hline & c. $2692 \mathrm{C}>\mathrm{T}$ \\
\hline
\end{tabular}

\begin{tabular}{l} 
Altered amino acid \\
\hline p.S33C \\
p.G34R \\
p.S45F \\
p.V426G_V427Q_A428_L433del \\
p.A547 \\
p.S45P \\
p.F14Y \\
p.L156F \\
p.R146 \\
p.I170V \\
p.G323A \\
p.R502H \\
p.P507L \\
p.T643M \\
p.P826H \\
p.R898W
\end{tabular}

Mutation type

Somatic

Somatic

Somatic

Somatic

Germline

Somatic

Germline

Germline

Germline

Germline

Germline

Germline

Germline

Germline

Germline

Germline

Splice site mutation are not included in the table. Accession numbers: aNM_001904.3, bNM_024742.2; APA, aldosterone-producing adenoma. 
these transgenic mice over a 17 -month period of time. Of note, female mice showed an aggressive progression in tumorigenesis (Berthon et al. 2010).

Recently, three different CTNNB1 mutations were identified in case studies of two pregnant and one postmenopausal woman (Teo et al. 2015). The identified mutations were at the target phosphorylation sites, p.S33C, p.S45F and p.G34C (Teo et al. 2015). Increased expression of luteinizing hormone-chorionic gonadotropin receptor $(L H-C G R)$ and gonadotropin-releasing hormone receptor (GNRHR) was identified in the adenomas. When the mutant CTNNB1 was expressed in an adrenal cell line, H295R, the expression of GATA4, a critical transcription factor during embryogenesis, was increased, which suggests that mutant CTNNB1 activates precursor cells in adrenal cortex.

\section{ARMC5}

The gene encoding for armadillo-repeat-containing 5 (ARMC5) is located on chromosome 16p11.2 and consists of 8 exons encoding for a protein of 1030 amino acids. ARMC5 belongs to the large family of armadillo (ARM)-repeat-containing proteins (ACPs). ACPs contain a common tandem repeat of 42 amino acids (Berthon \& Stratakis 2014). The three-dimensional structure of these proteins is highly conserved among ACPs; however, the structure of ARMC5 has yet to be determined. The best-known member of this family is $\beta$-catenin. Unlike $\beta$-catenin, the function of ARMC5 is still unknown, but the presence of tandem ARM-repeats suggests involvement in protein-protein interactions. Germline and somatic ARMC5 mutations have been reported earlier in adrenals from patients with Cushing syndrome (Assie et al. 2013).

Zilbermint and coworkers identified 12 different germline mutations in ARMC5 using samples from patients with APA (Fig. 8 and Table 6) (Zilbermint et al. 2015). The mutations were present in 39.3\% $(22 / 56)$ of the patients and distributed throughout the gene. All cases with predicted damaging mutations were of African-American origin. Nine mutations were germline missense mutations and three of them were germline splice site mutations. ARMC5 mutations were complementary to the KCNJ5 mutation, indicating a driving gene rather than a passenger gene. The expression of ARMC5 was downregulated in the mutated cells when compared with nonmutated APAs. Developmental abnormalities of the adrenal were found in mice and zebrafish harboring a loss-offunction mutation in ARMC5, which supports ARMC5's role as a tumor-suppressor gene (Assie et al. 2013, Faucz et al. 2014a,b). Furthermore, overexpression of mutant ARMC5 was found to downregulate CYP11B2 expression. Recently, Mulatero and coworkers also reported ARMC5 mutations in Caucasian patients (Mulatero et al. 2016). They identified 18 variants of ARMC5. However, the observed mutations were not associated with an altered protein function by in silica analysis. More studies are needed to clarify the role of ARMC5 in PA. It also appears that germline mutations of ARMC5 represent a new type of familial hyperaldosteronism.

\section{SLC26A2}

SLC26A2, located on chromosome 5q32, has at least three exons that encode the solute carrier 26 A2 transporter, a membrane protein of 739 amino acids that acts as a $\mathrm{SO}_{4}{ }^{2-} / \mathrm{Cl}^{-}$exchanger (Ohana et al. 2009). The $\mathrm{SO}_{4}{ }^{2-}$ ions transported by SLC26A 2 are important for the development of cartilage, and mutations in this gene have been associated with diastrophic dysplasia, achondrogenesis 1B, atelosteogenesis 2 (AO2) and multiple epiphyseal dysplasia 4 (EDM4) diseases.

Spyroglou and coworkers performed a genome-wide association study using a large population of patients with PA and controls (Spyroglou et al. 2014). It revealed an association with chromosome 5q32. The relevant gene present in this region was SLC26A2, which is downregulated in sporadic APAs. However, no mutation has been found in SLC26A2. Still, treatment with angiotensin II and induction of hypokalemia were found to downregulate SLC26A2 expression in mice. However, no morphological adrenal changes or adrenal tumors were observed in SLC26A2 knockin mice, but more aldosterone was produced. This study also addresses the possibility of epigenetic regulation, which could subsequently lead to the formation of sporadic APAs as well as increased aldosterone production.

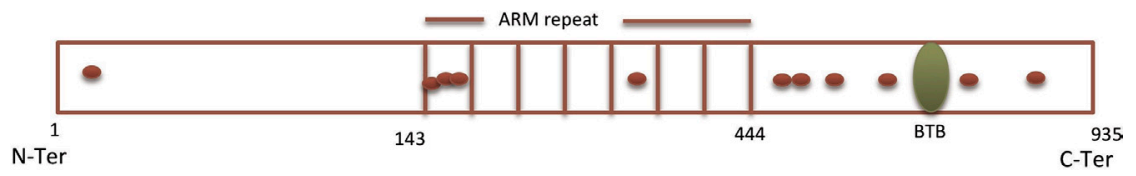

\section{Figure 8}

Structure of ARMC5. The red circles indicate mutations found in ARMC5 of patients with APA. Mutations are distributed throughout the protein. http://erc.endocrinology-journals.org DOI: 10.1530/ERC-16-0055
(C) 2016 Society for Endocrinology Printed in Great Britain
Published by Bioscientifica Ltd 


\section{The origin of APAs}

Mutations found in ion channel and transporter-related genes have clearly explained the underpinning cause of ectopic production of aldosterone in the majority of patients with PA (Fig. 9). However, tumor formation in the adrenal cortex is still unexplained and the cellular origin of sporadic APAs is controversial. Recent findings showed that mutational target genes determine the cellular composition of APAs. Upon histological examination, tumors harboring KCNJ5 mutations have a ZF-like cellular morphology (Azizan et al. 2012b). However, these tumors also express the biomarker of zona glomerulosa cells, disabled-2 (Dab-2). CACNA1D and ATPase mutants phenotypically resemble zona glomerulosa cells (Azizan et al. 2012b, Akerstrom et al. 2015). In contrast to previous results, Fernandes-Rosa and coworkers found that the majority of APAs were composed of heterogeneous cells and had a high percentage of ZF-like cells (FernandesRosa et al. 2014). In a similar study, Scholl and coworkers observed that tumors with KCNJ5 mutations phenotypically resemble ZF, whereas other mutations result in tumors with a more heterogeneous phenotype (Scholl et al. 2015a).

It has been debated whether adrenal cortex remodeling itself can lead to the development of APAs and whether somatic mutations in different genes are secondary, independent events. In recent studies, Dekkers and coworkers as well as Fernandes-Rosa and coworkers reported two different mutations in two different functional nodules of the same adrenal gland, which supports the concept of remodeling (Dekkers et al. 2014, Fernandes-Rosa et al. 2015). However, the underlying genetic mechanisms that lead to tumor formation are still unknown. Potential mechanisms could include the sonic hedgehog and/or the Wnt/ $\beta$ catenin signaling pathways (Boulkroun et al. 2011). Expression of both pathways has been found in a subset of APAs. Further, it is possible that $\beta$-catenin plays a role in gender-specific tumor formation in the adrenal cortex because the majority of somatic mutations in CTNNB1 are found in females with sporadic APAs (Tissier et al. 2005, Azizan et al. 2013, Teo et al. 2015, Scholl et al. 2015a, Akerstrom et al. 2016).

Several mouse models have been developed to study factors that contribute to the gender differences of APAs. Female TASK $^{-/-}$mice have a more severe phenotype than the corresponding males (Heitzmann et al. 2008). Female $T A S K 1^{-/-}$mice also have a compromised adrenal cortex zonation after puberty, and a higher expression of CYP11B2 was observed in the zone fasciculata. When female $\mathrm{TASK}^{-/-}$mice were treated with the male sex hormone, testosterone, a regression to normal aldosterone synthase expression was observed. Estrogen did not affect aldosterone production in either female or male knockout mice. Furthermore, female SLC26A2 knockin mice have been found to produce higher levels of aldosterone (Spyroglou et al. 2014). Nevertheless, adrenal tumors have never been found in any of the mouse models.

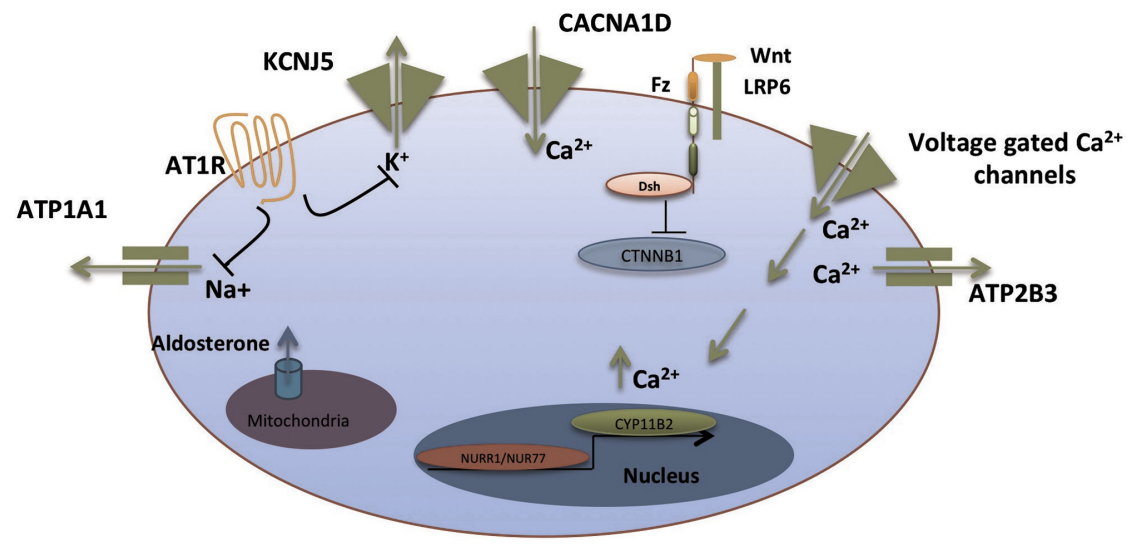

\section{Figure 9}

Pathways and channels involved in the biosynthesis of aldosterone. Under physiological conditions, binding of angiotensin II on angiotensin receptor type I (AT1R) activates the voltage-gated $\mathrm{Ca}^{2+}$ channels, which results into influx of $\mathrm{Ca}^{2+}$ ions. AT1R also elicit inositol 1,4,5-trisphosphate receptors (IP3Rs) to release $\mathrm{Ca}^{2+}$ release from the endoplasmic reticulum. Under pathological conditions, genes coding for $\mathrm{Na}^{+} / \mathrm{K}^{+-}$-ATPase, the potassium channels $K C N J 5$ or the $\mathrm{Ca}^{2+}$ ATPase and $\mathrm{Ca}^{2+}$ channel CACNA1D are mutated, leading to membrane depolarization and influx of calcium through voltage-gated calcium channel. Mutations in ATP2B3 affect the recycling of $\mathrm{Ca}^{2+}$. However, mutations in L-type $\mathrm{Ca}^{2+}$ channel CACNA1D lead to early opening at lower potential and a sustained activation of the channel, which increases the calcium influx. An increase in the intracellular calcium concentration is found to trigger the production of aldosterone. 
While critically analyzing data from previous publications concerning the age of patients and size of tumors between males and females, irrespective of mutational status (Choi et al. 2011, Dutta et al. 2014, Akerstrom et al. 2015, Scholl et al. 2015a), it became obvious that the majority of females were younger and had not entered menopause $(<50$ years $(N=56)$ vs $>50$ years $(N=26), P=0.0001)$. Although there was no size difference in the tumors before or after menopause, the aldosterone-to-renin ratio was higher before initiation of menopause $(289.5 \pm 44.2(N=56)$ vs $204.1 \pm 42.7(N=26)$, $P=0.26$ (mean \pm s.e.M)). On the contrary, males with APAs were older $(>50$ years $(N=70)$ vs $<50$ years $(N=40))$. In addition, the size of the tumors was significantly smaller in males than in females $(1.55 \pm 0.098 \mathrm{~cm}(N=110)$ vs $1.95 \pm 0.12 \mathrm{~cm}(N=82), P=0.0079)$. It is possible that sex hormones influence the development of adrenal tumors. Previous studies have shown that the androgen and estrogen receptors regulate the L-type voltage calcium channel, $\mathrm{Ca}_{\mathrm{v}} 1.3$, which is mutated in cases of sporadic APAs (Chen et al. 2014, Hao et al. 2015). We hypothesize that there is a gender-specific origin of APAs for several reasons. First, there is a gender bias among several of the mutations, and the majority of $\beta$-catenin mutations are found in females. Further, gender-specific differences are also observed in level of $\beta$-catenin activation and several mouse models. In females, APAs originate from the zona fasciculata, due to the activity of $\beta$-catenin, estrogen or unidentified pathways/genes. Moreover, mutations in ion channels and transporters activate aldosterone synthase. This results in morphological changes and zona glomerulosa-like phenotypes due to more metabolic activity. Another interesting observation is that $\beta$-catenin is frequently mutated in females with Cushing syndrome (Tissier et al. 2005, Goh et al. 2014). It is possible that tumors originate from zona fasciculate cells, and subsequent mutations in different genes cause the overproduction of different steroids. In male patients, the tumor originates from zona glomerulosa cells. There is not enough data to perform statistical analyses, but the available reports showed that $A T P 1 A 1$ and $C A C N A 1 D$ mutations were primarily found in males with smaller adenomas and higher aldosterone levels.

In summary, the cellular origin of sporadic APAs is still unclear. However, we propose a theory that the origin and regulation of sporadic APAs is gender specific. Clinical data, $\beta$-catenin expression and activation, tumor cell morphology and the expression of zona glomerulosa and zona fasciculata cell markers should all be examined in future studies. A comparison of males and females using large cohorts will increase our understanding of the cellular origin of APAs.

\section{Clinical consequences}

What is the clinical implication of all this knowledge? One clinical consequence might be more obvious in those cases arising from germline mutations. Here, family members harboring one of the mutations can be screened for the development of hypertension, leading to earlier diagnosis and treatment. Future research will tell us more about the prevalence of hypertension due to an APA in the presence of a specific germline mutation.

One important clinical issue is determining the subtype of PA in order to administer the appropriate treatment. Until now, AVS has been used as the gold standard for subtype's differentiation (APA/BAH). It requires a skilled radiologist. Recently, genotypespecific steroid profiles were found in the plasma of APA patients (Williams et al. 2016). This finding may be used in clinical practice to select PA patients that need to undergo AVS. The development of noninvasive imaging techniques could further improve the evaluation of patients with PA.

The question is whether specific nonsurgical treatments that take the underlying mutation into consideration can be developed. In the case of activating mutations, drugs blocking this activity are theoretically possible. In the case of inactivating mutations, the development of specific drugs may be more difficult. Because the mutations affect membrane-bound proteins, the development of specific antibodies would theoretically be possible. In order to create a definitive treatment, these antibodies could be conjugated to a radioactive substance that would kill cells recognized by the antibodies. Obviously, these antibodies would have to be very specific. Severe side effects of these potential nonsurgical treatments would not be acceptable, because the side effects of surgery are generally low and the underlying disease is benign.

In hereditary cases, the underlying mutation can be screened for by analyzing constitutive DNA. In sporadic cases, however, it is much more difficult to identify the mutation status. As shown in Table 2, it seems unlikely that one can predict the genotype by looking at the phenotype, even though some mutations seem to be associated with tumor size and a patient's age. Until we find the specific marker for each genotype, one has to get some tumor tissue from each adrenal nodule in order to be able to identify the specific mutation present in

Published by Bioscientifica Ltd 
that nodule. In theory, imaging techniques specific for a certain mutation would also be imaginable, but these techniques currently do not exist.

In summary, our knowledge of the underlying genetic mechanism leading to APAs is increasing. The development of specific therapies awaits further research.

\section{Declaration of interest}

The authors declare that there is no conflict of interest that could be perceived as prejudicing the impartiality of this review.

\section{Funding}

The authors did not receive any specific grants from any funding agencies in order to write this review.

\section{References}

Aglony M, Martinez-Aguayo A, Carvajal CA, Campino C, Garcia H, Bancalari R, Bolte L, Avalos C, Loureiro C, Trejo P, et al. 2011 Frequency of familial hyperaldosteronism type 1 in a hypertensive pediatric population clinical and biochemical presentation. Hypertension $\mathbf{5 7}$ 1117-1121. (doi:10.1161/HYPERTENSIONAHA.110.168740)

Akerstrom T, Willenberg HS, Cupisti K, Ip J, Backman S, Moser A, Maharjan R, Robinson B, Iwen KA, Dralle H, et al. 2015 Novel somatic mutations and distinct molecular signature in aldosteroneproducing adenomas. Endocrine-Related Cancer 22 735-744. (doi:10.1530/ERC-15-0321)

Akerstrom T, Maharjan R, Willenberg HS, Cupisti K, Ip J, Moser A, Stalberg P, Robinson B, Iwen KA, Dralle H, et al. 2016 Activating mutations in CTNNB1 in aldosterone producing adenomas. Scientific Reports 6 19546. (doi:10.1038/srep19546)

Anastas JN \& Moon RT 2013 WNT signalling pathways as therapeutic targets in cancer. Nature Reviews Cancer 13 11-26. (doi:10.1038/ nrc3419)

Angers S \& Moon RT 2009 Proximal events in Wnt signal transduction. Nature Reviews Molecular Cell Biology 10 468-477. (doi:10.1038/nrn2674)

Assie G, Libe R, Espiard S, Rizk-Rabin M, Guimier A, Luscap W, Barreau O, Lefevre L, Sibony M, Guignat L, et al. 2013 ARMC5 mutations in macronodular adrenal hyperplasia with Cushing's syndrome. New England Journal of Medicine 369 2105-2114. (doi:10.1056/NEJMoa1304603)

Azizan EA, Murthy M, Stowasser M, Gordon R, Kowalski B, Xu S, Brown MJ \& O'Shaughnessy KM 2012a Somatic mutations affecting the selectivity filter of KCNJ5 are frequent in 2 large unselected collections of adrenal aldosteronomas. Hypertension 59 587-591. (doi:10.1161/hypertensionaha.111.186239)

Azizan EAB, Lam BYH, Newhouse SJ, Zhou JH, Kuc RE, Clarke J, Happerfield L, Marker A, Hoffman GJ \& Brown MJ 2012b Microarray, qPCR, and KCNJ5 Sequencing of aldosterone-producing adenomas reveal differences in genotype and phenotype between zona glomerulosa- and zona fasciculata-like tumors. Journal of Clinical Endocrinology \& Metabolism 97 E819-E829. (doi:10.1210/jc.2011-2965)

Azizan EAB, Poulsen H, Tuluc P, Zhou J, Clausen MV, Lieb A, Maniero C, Garg S, Bochukova EG, Zhao W, et al. 2013 Somatic mutations in ATP1A1 and CACNA1D underlie a common subtype of adrenal hypertension. Nature Genetics 45 1055-1060. (doi:10.1038/ng.2716)

Baig SM, Koschak A, Lieb A, Gebhart M, Dafinger C, Nurnberg G, Ali A, Ahmad I, Sinnegger-Brauns MJ, Brandt N, et al. 2011 Loss of
$\mathrm{Ca}(\mathrm{v}) 1.3$ (CACNA1D) function in a human channelopathy with bradycardia and congenital deafness. Nature Neuroscience 14 77-86. (doi:10.1038/nn.2694)

Bassett MH, Suzuki T, Sasano H, White PC \& Rainey WE 2004 The orphan nuclear receptors NURR1 and NGFIB regulate adrenal aldosterone production. Molecular Endocrinology 18 279-290. (doi:10.1210/me.2003-0005)

Berthon A \& Stratakis CA 2014 From beta-catenin to ARM-repeat proteins in adrenocortical disorders. Hormone and Metabolic Research 46 889-896. (doi:10.1055/s-00000025)

Berthon A, Sahut-Barnola I, Lambert-Langlais S, de Joussineau C, Damon-Soubeyrand C, Louiset E, Taketo MM, Tissier F, Bertherat J, Kefrancois-Martinez AM, et al. 2010 Constitutive beta-catenin activation induces adrenal hyperplasia and promotes adrenal cancer development. Human Molecular Genetics 19 1561-1576. (doi:10.1093/ hmg/ddq029)

Berthon A, Drelon C, Ragazzon B, Boulkroun S, Tissier F, Amar L, Samson-Couterie B, Zennaro MC, Plouin PF, Skah S, et al. 2014 $\mathrm{WNT} /$ beta-catenin signalling is activated in aldosterone-producing adenomas and controls aldosterone production. Human Molecular Genetics 23 889-905. (doi:10.1093/hmg/ddt484)

Beuschlein F, Boulkroun S, Osswald A, Wieland T, Nielsen HN, Lichtenauer UD, Penton D, Schack VR, Amar L, Fischer E, et al. 2013 Somatic mutations in ATP1A1 and ATP2B3 lead to aldosteroneproducing adenomas and secondary hypertension. Nature Genetics 45 440-444. (doi:10.1038/ng.2550)

Boulkroun S, Samson-Couterie B, Golib-Dzib JF, Amar L, Plouin PF, Sibony M, Lefebvre H, Louiset E, Jeunemaitre X, Meatchi T, et al. 2011 Aldosterone-producing adenoma formation in the adrenal cortex involves expression of stem/progenitor cell markers. Endocrinology 152 4753-4763. (doi:10.1210/en.2011-1205)

Boulkroun S, Beuschlein F, Rossi GP, Golib-Dzib JF, Fischer E, Amar L, Mulatero P, Samson-Couterie B, Hahner S, Quinkler M, et al. 2012 Prevalence, clinical, and molecular correlates of KCNJ5 mutations in primary aldosteronism. Hypertension 59 592-598. (doi:10.1161/ HYPERTENSIONAHA.111.186478)

Cali T, Lopreiato R, Shimony J, Vineyard M, Frizzarin M, Zanni G, Zanotti G, Brini M, Shinawi M \& Carafoli E 2015 A novel mutation in isoform 3 of the plasma membrane Ca2+ pump impairs cellular $\mathrm{Ca} 2+$ homeostasis in a patient with cerebellar ataxia and laminin subunit 1 mutations. Journal of Biological Chemistry 290 16132-16141. (doi:10.1074/jbc.M115.656496)

Carvajal CA, Campino C, Martinez-Aguayo A, Tichauer JE, Bancalari R, Valdivia C, Trejo P, Aglony M, Baudrand R, Lagos CF, et al. 2012 A new presentation of the chimeric CYP11B1/CYP11B2 gene with low prevalence of primary aldosteronism and atypical gene segregation pattern. Hypertension 59 85-91. (doi:10.1161/ HYPERTENSIONAHA.111.180513)

Catterall WA 2011 Voltage-gated calcium channels. Cold Spring Harbor Perspectives in Biology 3 a003947. (doi:10.1101/cshperspect. a003947)

Chen RB, Zeng X, Zhang RT, Huang JT, Kuang XX, Yang J, Liu JH, Tawfik O, Thrasher JB \& Li BY $2014 \mathrm{Ca}(\mathrm{v}) 1.3$ channel alpha(1D) protein is overexpressed and modulates androgen receptor transactivation in prostate cancers. Urologic Oncology 32 524-536. (doi:10.1016/j.urolonc.2013.05.011)

Choi M, Scholl UI, Yue P, Bjorklund P, Zhao B, Nelson-Williams C, Ji W, Cho Y, Patel A, Men CJ, et al. $2011 \mathrm{~K}+$ channel mutations in adrenal aldosterone-producing adenomas and hereditary hypertension. Science 331 768-772. (doi:10.1126/science.1198785)

Conn JW 1966 The evolution of primary aldosteronism: 1954-1967. Harvey Lecture 62 257-291.

Corey S \& Clapham DE 1998 Identification of native atrial G-proteinregulated inwardly rectifying K(+) (GIRK4) channel homomultimers. Journal of Biological Chemistry 273 27499-27504. (doi:10.1074/ jbc.273.42.27499) http://erc.endocrinology-journals.org DOI: 10.1530/ERC-16-0055
๑ 2016 Society for Endocrinology Printed in Great Britain 
Czogalla J, Vohra T, Penton D, Kirschmann M, Craigie E \& Loffing J 2016 The mineralocorticoid receptor (MR) regulates $\mathrm{ENaC}$ but not NCC in mice with random MR deletion. Pflugers Archiv 468 849-858. (doi:10.1007/s00424-016-1798-5)

Dekkers T, ter Meer M, Lenders JWM, Hermus ARM, Kool LS, Langenhuijsen JF, Nishimoto K, Ogishima T, Mukai K, Azizan EAB, et al. 2014 Adrenal nodularity and somatic mutations in primary aldosteronism: one node is the culprit? Journal of Clinical Endocrinology \& Metabolism 99 E1341-E1351. (doi:10.1210/ jc. 2013-4255)

Dutta RK, Welander J, Brauckhoff M, Walz M, Alesina P, Arnesen T, Soderkvist P \& Gimm O 2014 Complementary somatic mutations of KCNJ5, ATP1A1, and ATP2B3 in sporadic aldosterone producing adrenal adenomas. Endocrine-Related Cancer 21 L1-L4. (doi:10.1530/ erc-13-0466)

Einholm AP, Andersen JP \& Vilsen B 2007 Importance of Leu(99) in transmembrane segment $\mathrm{M} 1$ of the $\mathrm{Na}+, \mathrm{K}+$-ATPase in the binding and occlusion of K+. Journal of Biological Chemistry $\mathbf{2 8 2}$ 23854-23866. (doi:10.1074/jbc.M702259200)

Fallo F, Pilon C, Williams TA, Sonino N, di Cella SM, Veglio F, De Iasio R, Montanari P \& Mulatero P 2004 Coexistence of different phenotypes in a family with glucocorticoid-remediable aldosteronism. Journal of Human Hypertension 18 47-51. (doi:10.1038/sj.jhh.1001636)

Faucz FR, Zilbermint M, Assie G, Lodish MB, Szarek E, Trivellin G, Berthon A, Sinaii N, Libe R, Espiard S, et al. 2014a Macronodular adrenal hyperplasia due to mutations in ARMC5: new mutations in humans and modeling in zebrafish. Cancer Research 742239. (doi:10.1158/1538-7445.am2014-2239)

Faucz FR, Zilbermint M, Lodish MB, Szarek E, Trivellin G, Sinaii N, Berthon A, Libe R, Assie G, Espiard S, et al. 2014b Macronodular adrenal hyperplasia due to mutations in an armadillo repeat containing 5 (ARMC5) gene: a clinical and genetic investigation. Journal of Clinical Endocrinology \& Metabolism 99 E1113-E1119. (doi:10.1210/jc.2013-4280)

Fernandes-Rosa FL, Williams TA, Riester A, Steichen O, Beuschlein F, Boulkroun S, Strom TM, Monticone S, Amar L, Meatchi T, et al. 2014 Genetic spectrum and clinical correlates of somatic mutations in aldosterone-producing adenoma. Hypertension 64 354-361. (doi:10.1161/HYPERTENSIONAHA.114.03419)

Fernandes-Rosa FL, Giscos-Douriez I, Amar L, Gomez-Sanchez CE, Meatchi T, Boulkroun S \& Zennaro MC 2015 Different somatic mutations in multinodular adrenals with aldosterone-producing adenoma. Hypertension 66 1014-1022. (doi:10.1161/ HYPERTENSIONAHA.115.05993)

Funder JW 2012 The genetic basis of primary aldosteronism. Current Hypertension Reports 14 120-124. (doi:10.1007/s11906-012-0255-x)

Funder JW, Carey RM, Fardella C, Gomez-Sanchez CE, Mantero F, Stowasser M, Young WF \& Montori VM 2008 Case detection, diagnosis, and treatment of patients with primary aldosteronism: an endocrine society clinical practice guideline. Journal of Clinical Endocrinology \& Metabolism 93 3266-3281. (doi:10.1210/ jc.2008-0104)

Gallo-Payet N 2016 Adrenal and extra-adrenal functions of ACTH. Journal of Molecular Endocrinology 56 T135-T156. (doi:10.1530/JME15-0257)

Garty H \& Palmer LG 1997 Epithelial sodium channels: function, structure, and regulation. Physiological Reviews 77 359-396.

Geller DS, Zhang J, Wisgerhof MV, Shackleton C, Kashgarian M \& Lifton RP 2008 A novel form of human mendelian hypertension featuring nonglucocorticoid-remediable aldosteronism. Journal of Clinical Endocrinology \& Metabolism 93 3117-3123. (doi:10.1210/ jc.2008-0594)

Goh G, Scholl UI, Healy JM, Choi M, Prasad ML, Nelson-Williams C, Kuntsman JW, Korah R, Suttorp AC, Dietrich D, et al. 2014 Recurrent activating mutation in PRKACA in cortisol-producing adrenal tumors (vol 46, pg 613, 2014). Nature Genetics 46 759-759. (doi:10.1038/ ng0714-759b)

Hao J, Bao XX, Jin B, Wang XJ, Mao ZB, Li XP, Wei LH, Shen DH \& Wang JL $2015 \mathrm{Ca} 2+$ channel subunit alpha 1D promotes proliferation and migration of endometrial cancer cells mediated by 17 beta-estradiol via the $\mathrm{G}$ protein-coupled estrogen receptor. FASEB Journal 29 2883-2893. (doi:10.1096/fj.14-265603)

Heginbotham L, Lu Z, Abramson T \& MacKinnon R 1994 Mutations in the $\mathrm{K}+$ channel signature sequence. Biophysical Journal $\mathbf{6 6}$ 1061-1067. (doi:10.1016/S0006-3495(94)80887-2)

Heinemann SH, Terlau H, Stuhmer W, Imoto K \& Numa S 1992 Calcium channel characteristics conferred on the sodium channel by single mutations. Nature 356 441-443. (doi:10.1038/356441a0)

Heitzmann D, Derand R, Jungbauer S, Bandulik S, Sterner C, Schweda F, El Wakil A, Lalli E, Guy N, Mengual R, et al. 2008 Invalidation of TASK1 potassium channels disrupts adrenal gland zonation and mineralocorticoid homeostasis. EMBO Journal 27 179-187. (doi:10.1038/sj.emboj.7601934)

Kim AC, Reuter AL, Zubair M, Else T, Serecky K, Bingham NC, Lavery GG, Parker KL \& Hammer GD 2008 Targeted disruption of beta-catenin in Sf1-expressing cells impairs development and maintenance of the adrenal cortex. Development 135 2593-2602. (doi:10.1242/dev.021493)

Lafferty AR, Torpy DJ, Stowasser M, Taymans SE, Lin JP, Huggard P, Gordon RD \& Stratakis CA 2000 A novel genetic locus for low renin hypertension: familial hyperaldosteronism type II maps to chromosome 7 (7p22). Journal of Medical Genetics 37 831-835. (doi:10.1136/jmg.37.11.831)

Lifton RP, Dluhy RG, Powers M, Rich GM, Cook S, Ulick S \& Lalouel JM 1992a A chimeric 11-beta-hydroxylase aldosterone synthase gene causes glucocorticoid-remediable aldosteronism and human hypertension. Nature 355 262-265. (doi:10.1038/355262a0)

Lifton RP, Dluhy RG, Powers M, Rich GM, Gutkin M, Fallo F, Gill JR, Feld L, Ganguly A, Laidlaw JC, et al. 1992b Hereditary hypertension caused by chimeric gene duplications and ectopic expression of aldosterone synthase. Nature Genetics 2 66-74. (doi:10.1038/ ng0992-66)

Lipscombe D, Helton TD \& Xu WF 2004 L-type calcium channels: the low down. Journal of Neurophysiology 92 2633-2641. (doi:10.1152/ jn.00486.2004)

Litchfield WR, Anderson BF, Weiss RJ, Lifton RP \& Dluhy RG 1998 Intracranial aneurysm and hemorrhagic stroke in glucocorticoidremediable aldosteronism. Hypertension 31 445-450. (doi:10.1161/01. HYP.31.1.445)

Marionneau C, Couette B, Liu J, Li HY, Mangoni ME, Nargeot J, Lei M, Escande D \& Demolombe S 2005 Specific pattern of ionic channel gene expression associated with pacemaker activity in the mouse heart. Journal of Physiology 562 223-234. (doi:10.1113/ jphysiol.2004.074047)

Marksteiner R, Schurr P, Berjukow S, Margreiter E, Perez-Reyes E \& Hering S 2001 Inactivation determinants in segment IIIS6 of $\mathrm{Ca}(\mathrm{v}) 3.1$. Journal of Physiology 537 27-34. (doi:10.1111/j.1469-7793.2001.0027k.x)

Mintert E, Bosche LI, Rinne A, Timpert M, Kienitz MC, Pott L \& Bender K 2007 Generation of a constitutive Na+-dependent inwardrectifier current in rat adult atrial myocytes by overexpression of Kir3.4. Journal of Physiology 585 3-13. (doi:10.1113/ jphysiol.2007.140772)

Monticone S, Hattangady NG, Nishimoto K, Mantero F, Rubin B, Cicala MV, Pezzani R, Auchus RJ, Ghayee HK, Shibata H, et al. 2012 Effect of KCNJ5 mutations on gene expression in aldosteroneproducing adenomas and adrenocortical cells. Journal of Clinical Endocrinology \& Metabolism 97 E1567-E1572. (doi:10.1210/ jc. 2011-3132)

Monticone S, Hattangady NG, Penton D, Isales CM, Edwards MA, Williams TA, Sterner C, Warth R, Mulatero P \& Rainey WE 2013 
A novel Y152C KCNJ5 mutation responsible for familial hyperaldosteronism type III. Journal of Clinical Endocrinology \& Metabolism 98 E1861-E1865. (doi:10.1210/jc.2013-2428)

Monticone S, Bandulik S, Stindl J, Zilbermint M, Dedov I, Mulatero P, Allgaeuer M, Lee CCR, Stratakis CA, Williams TA, et al. 2015a A case of severe hyperaldosteronism caused by a de novo mutation affecting a critical salt bridge Kir3.4 residue. Journal of Clinical Endocrinology \& Metabolism 100 E114-E118. (doi:10.1210/ jc.2014-3636)

Monticone S, Else T, Mulatero P, Williams TA \& Rainey WE 2015b Understanding primary aldosteronism: impact of next generation sequencing and expression profiling. Molecular and Cellular Endocrinology 399 311-320. (doi:10.1016/j.mce.2014.09.015)

Morgan L, Pipkin FB \& Kalsheker N 1996 Angiotensinogen: molecular biology, biochemistry and physiology. International Journal of Biochemistry \& Cell Biology 28 1211-1222. (doi:10.1016/S13572725(96)00086-6)

Morin PJ, Sparks AB, Korinek V, Barker N, Clevers H, Vogelstein B \& Kinzler KW 1997 Activation of beta-catenin-Tcf signaling in colon cancer by mutations in beta-catenin or APC. Science 275 1787-1790. (doi:10.1126/science.275.5307.1787)

Morth JP, Pedersen BP, Toustrup-Jensen MS, Sorensen TLM, Petersen J, Andersen JP, Vilsen B \& Nissen P 2007 Crystal structure of the sodium-potassium pump. Nature 450 1043-1049. (doi:10.1038/ nature06419)

Mulatero P, Tizzani D, Viola A, Bertello C, Monticone S, Mengozzi G, Schiavone D, Williams TA, Einaudi S, La Grotta A, et al. 2011 Prevalence and characteristics of familial hyperaldosteronism: the PATOGEN study (Primary Aldosteronism in TOrino-GENetic forms). Hypertension 58 797-803. (doi:10.1161/HYPERTENSIONAHA. 111.175083)

Mulatero P, Tauber P, Zennaro MC, Monticone S, Lang K, Beuschlein F, Fischer E, Tizzani D, Pallauf A, Viola A, et al. 2012 KCNJ5 mutations in European families with nonglucocorticoid remediable familial hyperaldosteronism. Hypertension 59 235-240. (doi:10.1161/ HYPERTENSIONAHA.111.183996)

Mulatero P, Schiavi F, Williams TA, Monticone S, Barbon G, Opocher G \& Fallo F 2016 ARMC5 mutation analysis in patients with primary aldosteronism and bilateral adrenal lesions. Journal of Human Hypertension 30 374-378. (doi:10.1038/jhh.2015.98)

Murthy M, Xu SX, Massimo G, Wolley M, Gordon RD, Stowasser M \& O'Shaughnessy KM 2014 Role for germline mutations and a rare coding single nucleotide polymorphism within the KCNJ5 potassium channel in a large cohort of sporadic cases of primary aldosteronism. Hypertension 63 783-789. (doi:10.1161/HYPERTENSIONAHA. 113.02234)

Nishikawa T, Omura M, Satoh F, Shibata H, Takahashi K, Tamura N, Tanabe A \& Soc JE 2011 Guidelines for the diagnosis and treatment of primary aldosteronism - The Japan Endocrine Society 2009. Endocrine Journal 58 711-721. (doi:10.1507/endocrj.EJ11-0133)

Nishimoto K, Nakagawa K, Li D, Kosaka T, Oya M, Mikami S, Shibata H, Itoh H, Mitani F, Yamazaki T, et al. 2010 Adrenocortical zonation in humans under normal and pathological conditions. Journal of Clinical Endocrinology \& Metabolism 95 2296-2305. (doi:10.1210/ jc.2009-2010)

Nishimoto K, Tomlins SA, Kuick R, Cani AK, Giordano TJ, Hovelson DH, Liu CJ, Sanjanwala AR, Edwards MA, Gomez-Sanchez CE, et al. 2015 Aldosterone-stimulating somatic gene mutations are common in normal adrenal glands. PNAS 112 E4591-E4599. (doi:10.1073/ pnas.1505529112)

Ohana E, Yang D, Shcheynikov N \& Muallem S 2009 Diverse transport modes by the solute carrier 26 family of anion transporters. Journal of Physiology 587 2179-2185. (doi:10.1113/jphysiol.2008.164863)

Pascoe L, Curnow KM, Slutsker L, Connell JMC, Speiser PW, New MI \& White PC 1992 Glucocorticoid-suppressible hyperaldosteronism results from hybrid genes created by unequal crossovers between
Cyp11b1 and Cyp11b2. PNAS 89 8327-8331. (doi:10.1073/ pnas.89.17.8327)

Pinggera A, Lieb A, Benedetti B, Lampert M, Monteleone S, Liedl KR, Tuluc P \& Striessnig J 2015 CACNA1D de novo mutations in autism dpectrum disorders activate Cav1.3 L-type calcium channels. Biological Psychiatry 77 816-822. (doi:10.1016/j.biopsych. 2014.11.020)

Rossier BC, Staub O \& Hummler E 2013 Genetic dissection of sodium and potassium transport along the aldosterone-sensitive distal nephron: importance in the control of blood pressure and hypertension. FEBS Letters 587 1929-1941. (doi:10.1016/j. febslet.2013.05.013)

Roux B 2005 Ion conduction and selectivity in $\mathrm{K}(+)$ channels. Annual Review of Biophysics and Biomolecular Structure 34 153-171. (doi:10.1146/annurev.biophys.34.040204.144655)

Scholl UI, Nelson-Williams C, Yue P, Grekin R, Wyatt RJ, Dillon MJ, Couch R, Hammer LK, Harley FL, Farhi A, et al. 2012 Hypertension with or without adrenal hyperplasia due to different inherited mutations in the potassium channel KCNJ5. PNAS 109 2533-2538. (doi:10.1073/pnas.1121407109)

Scholl UI, Goh G, Stolting G, de Oliveira RC, Choi M, Overton JD, Fonseca AL, Korah R, Starker LF, Kunstman JW, et al. 2013 Somatic and germline CACNA1D calcium channel mutations in aldosteroneproducing adenomas and primary aldosteronism. Nature Genetics $\mathbf{4 5}$ 1050-1054. (doi:10.1038/ng.2695)

Scholl UI, Healy JM, Thiel A, Fonseca AL, Brown TC, Kunstman JW, Horne MJ, Dietrich D, Riemer J, Kucukkoylu S, et al. 2015a Novel somatic mutations in primary hyperaldosteronism are related to the clinical, radiological and pathological phenotype. Clinical Endocrinology 83 779-789. (doi:10.1111/cen.12873)

Scholl UI, Stolting G, Nelson-Williams C, Vichot AA, Choi M, Loring E, Prasad ML, Goh G, Carling T, Juhlin CC, et al. 2015b Recurrent gain of function mutation in calcium channel CACNA1H causes earlyonset hypertension with primary aldosteronism. eLife 4 e06315. (doi:10.7554/elife.06315)

Shaikh LH, Zhou JH, Teo AED, Garg S, Neogi SG, Figg N, Yeo GS, Yu HX, Maguire JJ, Zhao WF, et al. 2015 LGR5 activates noncanonical Wnt signaling and inhibits aldosterone production in the human adrenal. Journal of Clinical Endocrinology \& Metabolism 100 E836-E844. (doi:10.1210/jc.2015-1734)

Share L \& Crofton JT 1982 Contribution of vasopressin to hypertension. Hypertension 4 85-92.

So A, Duffy DL, Gordon RD, Jeske YWA, Lin-Su K, New MI \& Stowasser M 2005 Familial hyperaldosteronism type II is linked to the chromosome $7 \mathrm{p} 22$ region but also shows predicted heterogeneity. Journal of Hypertension 23 1477-1484. (doi:10.1097/01. hjh.0000174299.66369.26)

Spat A 2004 Glomerulosa cell - a unique sensor of extracellular K+ concentration. Molecular and Cellular Endocrinology 217 23-26. (doi:10.1016/j.mce.2003.10.046)

Spyroglou A, Bozoglu T, Rawal R, De Leonardis F, Sterner C, Boulkroun S, Benecke AG, Monti L, Zennaro MC, Petersen AK, et al. 2014 Diastrophic dysplasia sulfate transporter (SLC26A2) is expressed in the adrenal cortex and regulates aldosterone secretion. Hypertension 63 1102-1109. (doi:10.1161/HYPERTENSIONAHA.113.02504)

Stindl J, Tauber P, Sterner C, Tegtmeier I, Warth R \& Bandulik S 2015 Pathogenesis of adrenal aldosterone-producing adenomas carrying mutations of the Na+/K+-ATPase. Endocrinology 156 4582-4591. (doi:10.1210/en.2015-1466)

Stowasser M, Gordon RD, Tunny TJ, Klemm SA, Finn WL \& Krek AL 1992 Familial hyperaldosteronism type-Ii -5 families with a new variety of primary aldosteronism. Clinical and Experimental Pharmacology and Physiology 19 319-322. (doi:10.1111/j.1440-1681.1992.tb00462.x)

Sukor N, Mulatero P, Gordon RD, So A, Duffy D, Bertello C, Kelemen L, Jeske Y, Veglio F \& Stowasser M 2008 Further evidence for linkage of familial hyperaldosteronism type II at chromosome 7p22 in Italian

Published by Bioscientifica Ltd. 
as well as Australian and South American families. Journal of Hypertension 26 1577-1582. (doi:10.1097/HJH.0b013e3283028352)

Sutherland DJ, Ruse JL \& Laidlaw JC 1966 Hypertension, increased aldosterone secretion and low plasma renin activity relieved by dexamethasone. Canadian Medical Association Journal 95 1109-1119.

Taguchi R, Yamada M, Nakajima Y, Satoh T, Hashimoto K, Shibusawa N, Ozawa A, Okada S, Rokutanda N, Takata D, et al. 2012 Expression and mutations of KCNJ5 mRNA in Japanese patients with aldosterone-producing adenomas. Journal of Clinical Endocrinology \& Metabolism 97 1311-1319. (doi:10.1210/jc.2011-2885)

Tanabe A, Naruse M, Arai K, Naruse K, Yoshimoto T, Seki T, Imaki T, Kobayashi M, Miyazaki H \& Demura H 1998 Angiotensin II stimulates both aldosterone secretion and DNA synthesis via type 1 but not type 2 receptors in bovine adrenocortical cells. Journal of Endocrinological Investigation 21 668-672. (doi:10.1007/ BF03350796)

Teo AED, Garg S, Shaikh LH, Zhou J, Frankl FEK, Gurnell M, Happerfield L, Marker A, Bienz M, Azizan EAB, et al. 2015 Pregnancy, primary aldosteronism, and adrenal CTNNB1 mutations. New England Journal of Medicine 373 1429-1436. (doi:10.1056/NEJMoa1504869)

Tissier F, Cavard C, Groussin L, Perlemoine K, Fumey G, Hagnere AM, Rene-Corail F, Jullian E, Gicquel C, Bertagna X, et al. 2005 Mutations of beta-catenin in adrenocortical tumors: activation of the wnt signaling pathway is a frequent event in both benign and malignant adrenocortical tumors. Cancer Research 65 7622-7627.
Williams TA, Monticone S, Schack VR, Stindl J, Burrello J, Buffolo F, Annaratone L, Castellano I, Beuschlein F, Reincke M, et al. 2014 Somatic ATP1A1, ATP2B3, and KCNJ5 mutations in aldosteroneproducing adenomas. Hypertension 63 188-195. (doi:10.1161/ HYPERTENSIONAHA.113.01733)

Williams TA, Lenders JWM, Burrello J, Beuschlein F \& Reincke M 2015 KCNJ5 mutations: sex, salt and selection. Hormone and Metabolic Research 47 953-958. (doi:10.1055/s-00000025)

Williams TA, Peitzsch M, Dietz AS, Dekkers T, Bidlingmaier M, Riester A, Treitl M, Rhayem Y, Beuschlein F, Lenders JWM, et al. 2016 Genotype-specific steroid profiles associated with aldosteroneproducing adenomas. Hypertension 67 139-145. (doi:10.1161/ HYPERTENSIONAHA.115.06186)

Yang YZ, Yang YQ, Liang B, Liu JQ, Li J, Grunnet M, Olesen SP, Rasmussen HB, Ellinor PT, Gao LJ, et al. 2010 Identification of a Kir3.4 mutation in congenital long QT syndrome. American Journal of Human Genetics 86 872-880. (doi:10.1016/j.ajhg.2010.04.017)

Zennaro MC, Fernandes-Rosa F, Boulkroun S \& Jeunemaitre X 2015 Bilateral idiopathic adrenal hyperplasia: genetics and beyond. Hormone and Metabolic Research 47 947-952. (doi:10.1055/s-00000025)

Zilbermint M, Xekouki P, Faucz FR, Berthon A, Gkourogianni A, Schernthaner-Reiter MH, Batsis M, Sinaii N, Quezado MM, Merino M, et al. 2015 Primary aldosteronism and ARMC5 variants. Journal of Clinical Endocrinology \& Metabolism 100 E900-E909. (doi:10.1210/jc.2014-4167)

Received in final form 8 July 2016

Accepted 1 August 2016

Accepted Preprint published online 2 August 2016
๑) 2016 Society for Endocrinology Printed in Great Britain
Published by Bioscientifica Ltd. 